Notre Dame Law School

NDLScholarship

Journal Articles

Publications

2009

\title{
Pretextual Takings: Of Private Developers, Local Governments, and Impermissible Favoritism
}

Daniel B. Kelly

Notre Dame Law School, daniel.kelly@nd.edu

Follow this and additional works at: https://scholarship.law.nd.edu/law_faculty_scholarship

Part of the State and Local Government Law Commons

\section{Recommended Citation}

Daniel B. Kelly, Pretextual Takings: Of Private Developers, Local Governments, and Impermissible Favoritism, 17 Sup. Ct. Econ. Rev. 173 (2009).

Available at: https://scholarship.law.nd.edu/law_faculty_scholarship/689

This Article is brought to you for free and open access by the Publications at NDLScholarship. It has been accepted for inclusion in Journal Articles by an authorized administrator of NDLScholarship. For more information, please contact lawdr@nd.edu. 


\section{CHICAGO JOURNALS}

Pretextual Takings: Of Private Developers, Local Governments, and Impermissible Favoritism Author(s): Daniel B. Kelly

Source: Supreme Court Economic Review, Vol. 17, No. 1 (February 2009), pp. 173-235

Published by: The University of Chicago Press

Stable URL: http://www.jstor.org/stable/10.1086/656056

Accessed: $14 / 10 / 2013$ 10:52

Your use of the JSTOR archive indicates your acceptance of the Terms \& Conditions of Use, available at http://www.jstor.org/page/info/about/policies/terms.jsp

JSTOR is a not-for-profit service that helps scholars, researchers, and students discover, use, and build upon a wide range of content in a trusted digital archive. We use information technology and tools to increase productivity and facilitate new forms of scholarship. For more information about JSTOR, please contact support@jstor.org. 


\title{
Pretextual Takings: Of Private Developers, Local Governments, and Impermissible Favoritism
}

\author{
Daniel B. Kelly*
}

\begin{abstract}
Since Kelo v. City of New London, the preferred litigation strategy for challenging a condemnation that benefits a private party is to allege that the taking is "pretextual." This Article contends that, although pretextual takings are socially undesirable, the current judicial test for identifying such takings is problematic. Yet an alternative, intent-based test might be impracticable, as well as underinclusive: condemnors often have mixed motives, particularly when confronted with a firm's credible threat to relocate. Instead, the Article develops a framework that emphasizes informational differences between local governments and private developers. When the government lacks information regarding the optimal site for an assembly, the government may need to rely on a private party to identify, as well as develop, a particular site. However, when the government itself possesses information regarding the site, pre-condemnation private involvement, as well as post-condemnation involvement by a preferred developer, is generally unnecessary. Such involvement increases the likelihood of a pretextual transfer without any corresponding public benefit. The Article concludes that a burden-shifting framework, analogous to Title VII's test for identifying pretext, can be adopted in the takings context. The new framework is then applied to several situations in which allegations of pretext are likely to arise.
\end{abstract}

* Terence M. Considine Research Fellow in Law and Economics and Lecturer on Law, Harvard Law School. J.D., Harvard Law School; B.A., University of Notre Dame (dkelly@post.harvard.edu). I thank Robert Ellickson, Thomas Merrill, Steven Shavell, and Ilya Somin for helpful suggestions. I also am grateful to the Thomas W. Smith 


\section{I N T R O D U C T I O N}

In the wake of the Supreme Court's decision in Kelo v. City of New London, ${ }^{1}$ the underlying assumption of Kelo's critics, as well as its defenders, has been that, when compared with Justice O'Connor's dissenting opinion, the opinion of the Court is less protective of private property rights. In at least one respect, however, the Court's opinion arguably is more protective of property rights than $\mathrm{O}^{\prime}$ Connor's dissent. Whereas $\mathrm{O}^{\prime}$ Connor appeared to suggest that the government's motivation for a taking is irrelevant, the Court acknowledged the possibility that a condemnation might violate the Public Use Clause of the Fifth Amendment if its purpose was pretextual. ${ }^{2}$

Although Kelo is the first eminent domain case in which the Court considered this issue of pretext, ${ }^{3}$ the Court failed to provide much guidance. Writing for the Court, Justice Stevens briefly mentioned two reasons for concluding that the takings at issue were not pretextual: the condemnations "would be executed pursuant to a carefully considered development plan" and "the identities of th[e] private parties were not known when the plan was adopted." ${ }^{4}$ In a concur-

Foundation, the John M. Olin Center for Law, Economics, and Business at Harvard Law School, and Yale Law School, where I completed most of the work on this Article as an Olin Fellow, for research support.

${ }^{1} 545$ US 469 (2005) (holding that a city's use of eminent domain to transfer property from one private party to another private party does not violate the Public Use Clause of the Fifth Amendment- "nor shall private property be taken for public use, without just compensation"-if the condemnation may have an incidental public benefit of promoting economic development).

${ }^{2}$ Compare id at 478 (Stevens) (asserting that a city would not be allowed "to take property under the mere pretext of a public purpose, when its actual purpose was to bestow a private benefit" (emphasis added)) with id at 502 (O'Connor dissenting) ("If it is true that incidental public benefits from new private use are enough to ensure the 'public purpose' in a taking, why should it matter, as far as the Fifth Amendment is concerned, what inspired the taking in the first place?").

${ }^{3}$ See Goldstein v Pataki, 516 F3d 50, 61 (2d Cir 2008) ("Prior to Kelo, no Supreme Court decision had endorsed the notion of a 'pretext' claim ....") The term "pretext" did appear in West River Bridge Co v Dix, 47 US 507 (1848), but the reference is merely a quotation from Kent's Commentaries, id at 519 (quoting 2 Kent's Comm 340).

${ }^{4} \mathrm{Kelo}, 545$ US at 478 \& $\mathrm{n} 6$ (internal quotation marks and citations omitted). Justice Stevens also cited one case, 99 Cents Only Stores v Lancaster Redevelopment Agency, 237 F Supp 2d 1123 (CD Cal 2001), for the proposition that "a one-to-one transfer of property, executed outside the confines of an integrated development plan ... would certainly raise a suspicion that a private purpose was afoot ...." Kelo, 545 US at 487 \& n 17. However, because the condemnation in 99 Cents Only did occur pursuant to a development plan the discussion of pretext proved to be ambiguous as well as brief. 99 Cents Only, 237 F Supp 2d at 1125; see Ilya Somin, Controlling the Grasping Hand: Economic Development Takings After Kelo, 15 S Ct Econ Rev 183, 236 (2007) 
ring opinion, Justice Kennedy indicated that his agreement with the Court did not "foreclose the possibility that a more stringent standard of review ... might be appropriate for a more narrowly drawn category of takings." Kennedy highlighted two additional factors, the expected public benefits of the project and the city's compliance with procedural requirements, in concluding that a "more demanding" standard was inappropriate for a case like Kelo. ${ }^{6}$ However, it is unclear whether each of these four factors (or perhaps some combination of them) is determinative or even whether these factors should be determinative. ${ }^{7}$

Notwithstanding the general backlash against eminent domain since $\mathrm{Kelo}^{8}{ }^{8}$ the specific issue of pretext has received relatively little legislative attention. Only one state, Georgia, mentioned "pretext" in its statutory law before Kelo. ${ }^{9}$ Only two others, Texas and Idaho, enacted similar provisions after Kelo. ${ }^{10}$ Yet even the statutes in these three states merely indicate that pretextual takings are prohibited; they do not provide any criterion by which a taking might be identi-

(noting that "even ... the case that Stevens' opinion cites as a paradigmatic example of impermissible favoritism" involved a plan).

${ }^{5}$ Kelo, 545 US at 493 (Kennedy concurring).

${ }^{6}$ Overall, Kennedy emphasized that (i) "the projected economic benefits of the project cannot be characterized as de minimis"; (ii) "the taking occurred in the context of a comprehensive development plan"; (iii) "[t]he city complied with elaborate procedural requirements"; and (iv) "[t]he identities of most of the private beneficiaries were unknown at the time the city formulated its plans." Id.

${ }^{7}$ See Franco v Nat'l Capital Revitalization Corp, 930 A2d 160, 169 (DC 2007) (suggesting that "the Supreme Court's decision may raise many more questions than it answers"); Julia D. Mahoney, Kelo's Legacy: Eminent Domain and the Future of Property Rights, 2005 Sup Ct Rev 103, 120 (asserting that Kennedy's factors "raise more questions than they answer about when departure from the rational basis framework might be warranted").

${ }^{8}$ See Andrew P. Morriss, Symbol or Substance? An Empirical Assessment of State Responses to Kelo, 17 S Ct Econ Rev 237 (2009) ("In the two years after the June 23, 2005 decision, legislation to restrict eminent domain powers was introduced in fortysix states, with multiple bills in many states, and forty-two states enacted legislation or constitutional amendments restricting the use of eminent domain.").

${ }^{9}$ See Ga Code Ann, § 22-1-3 ("It is the province of the General Assembly to determine when the right of eminent domain may be exercised. If, however, under pretext of such necessity the General Assembly should pass a law authorizing the taking of property for private use rather than for public use, the courts should declare the law inoperative.").

${ }^{10}$ See Texas SB 7 (Sept. 1, 2005) ("A governmental or private entity may not take private property through the use of eminent domain if the taking . . . is for a public use that is merely a pretext to confer a private benefit on a particular private party ...."); Idaho HB 555 (Mar. 21, 2006) ("Eminent domain shall not be used to acquire private property ... [f]or any alleged public use which is merely a pretext for the transfer of the condemned property or any interest in that property to a private party ...."). 
fied as pretextual. In light of the Court's holding that the particular condemnations at issue were not pretextual, ${ }^{11}$ the Court's reluctance to articulate a clear test for determining whether a taking is pretextual, and the dissent's skepticism about whether pretext is even relevant, a more robust legislative response may have been warranted..$^{12}$

The legislatures' lack of attention, coupled with the Court's lack of clarity, has created significant uncertainty for both litigants and lower courts. In several post-Kelo cases, litigants have attempted to invoke the Court's reference to "pretext" in challenging condemnations that allegedly benefit private parties. ${ }^{13}$ However, in deciding these cases, lower courts have relied on a number of different analytical frameworks and reached a number of different substantive conclusions. There are disagreements about whether a condemnor's motivation matters; whether, if motivation does matter, there are ways for courts to identify it; what the Supreme Court's "test" for pretext actually requires; and whether, and to what extent, the various factors in Justice Kennedy's concurrence should be utilized as persuasive authority. ${ }^{14}$ Yet, despite this uncertainty, it is unlikely that the Supreme Court will provide further clarification in the near future.

In this Article, I propose a new framework for evaluating whether a taking is pretextual. In Part II, I examine whether pretextual takings are, in fact, problematic. I contend that unlimited private involvement may result in a number of problems including corruption, secondary rent seeking, and threats to relocate, each of which may increase the likelihood of undesirable transfers. ${ }^{15} \mathrm{I}$ also consider three of the most significant arguments against judicial consideration of

${ }^{11}$ See Kelo, 545 US at 478 (holding that "the City's development plan was not adopted 'to benefit a particular class of identifiable individuals'" (quoting Hawaii Housing Authority v Midkiff, 467 US 229, 245 (1984)).

${ }^{12} \mathrm{~A}$ few states did enact procedural reforms aimed at reducing the likelihood of abuse. See, for example, Minn SF 2750 (May 19, 2006) (requiring a public hearing and a resolution describing, inter alia, the "public costs and benefits"). These reforms may increase, what Thomas Merrill has called, the "due process costs" of eminent domain. Thomas W. Merrill, The Economics of Public Use, 72 Cornell L Rev 61, 87 (1986). Yet procedural requirements only address the issue of pretext indirectly. See Part III/A)(2).

${ }^{13}$ See, for example, Goldstein, 516 F3d 50; Franco, 930 A2d 160; Middletown Township $v$ Lands of Stone, 939 A2d 331 (Pa 2007); 49 WB, LLC V Village of Haverstraw, 44 AD3d 226 (NY App Div 2007); Didden v Village of Port Chester, 2006 US App LEXIS 8653, 2006 WL 898093 (2d Cir 2006).

${ }^{14} \mathrm{Cf}$. Kelo, 545 US at 502 (O'Connor dissenting) (criticizing the Court's opinion for not "detailing how courts are to conduct th[e] complicated inquiry" into pretextual motivation and Kennedy's concurrence for not "specifying what courts should look for in a case with different facts, how they will know if they have found it, and what to do if they do not"1.

${ }^{15}$ See Part II(A). 
pretext: disutility, futility, and judicial administrability. ${ }^{16}$ I conclude that implementing a framework for evaluating pretext is likely to be worthwhile only if these objections can be overcome.

In Part III, I identify several problems with the current test, as articulated in the majority and concurring opinions in Kelo and the subsequent decisions of lower federal and state courts. ${ }^{17} \mathrm{I}$ then suggest why one plausible alternative, a test based on the condemnor's motivation, is impracticable, as well as underinclusive. ${ }^{18}$ The shortcomings of these tests suggest the need for a different approach.

In Part IV, I outline a new approach based on the comparative competencies of public and private actors. I first point out that assembly projects actually involve two distinct stages, identification of the assembly site and development of the assembly site. ${ }^{19} \mathrm{I}$ then contend that, because private parties play a different role at each stage, a local government may need to rely on private parties for certain types of takings but not others. ${ }^{20}$ Specifically, when the government itself has information regarding the optimal site, pre-condemnation private involvement, as well as post-condemnation involvement by a preferred developer, is generally unnecessary. Under these circumstances, the expected costs of private involvement almost certainly outweigh its potential benefits. By contrast, when the government does not have information regarding the optimal site, pre-condemnation private involvement may be necessary to identify the site. In these situations, allocating development rights through auctions or other competitive mechanisms aimed at reducing the likelihood of pretext might eliminate the incentive for certain developers to reveal socially useful information.

In Part V, I suggest that either legislatures or courts might implement this theory on either the state or federal level by adopting a burden-shifting test similar to the framework for identifying pretext in adverse employment actions under Title VII. ${ }^{21}$ I illustrate how this framework might apply in the takings context by considering condemnations in blighted areas as well as situations involving redevelopment districts, new assemblies, positive externalities, changed circumstances, one-to-one transfers, and "same-use" takings. ${ }^{22}$

Finally, in Part VI, I conclude with several predictions regarding the likely role of pretextual analysis in eminent domain law. I main-

\footnotetext{
${ }^{16}$ See Part II(B).

${ }^{17}$ See Part III(A).

${ }^{18}$ See Part III(B).

${ }^{19}$ See Part IV(A).

${ }^{20}$ See Part IV(B).

${ }^{21}$ See Part V(A).

${ }^{22}$ See Part V(B).
} 
tain that a failure to develop a coherent jurisprudence of pretext could result in excessive judicial deference or excessive judicial discretion, either of which might exacerbate the public's reaction against Kelo.

\section{DESIRABILITY OF TARGETING P R E T E X T}

\section{A. Risks of Private Involvement}

Allowing unlimited private involvement in the eminent domain process raises a number of potential concerns. ${ }^{23}$ First, private involvement may increase the risk of corruption and inordinate influence. Certain private parties may use side payments, bribes, kickbacks, lobbyists, and campaign contributions to encourage local officials to approve takings that are not in the public interest. ${ }^{24}$ While taxpayers

${ }^{23}$ Elsewhere, I have argued that the necessity of utilizing eminent domain on behalf of private parties may be overstated: private parties, unlike the government, often can overcome strategic holdouts without relying on eminent domain. See generally Daniel B. Kelly, The "Public Use" Requirement in Eminent Domain Law: A Rationale Based on Secret Purchases and Private Influence, 92 Cornell L Rev 1, 18-33 (2006); see also Robert C. Ellickson and Vicki L. Been, Land Use Controls: Cases and Materials 845-54 (Aspen Publishers 3d ed 2005) (discussing ability of private firms to assemble land without resorting to eminent domain). In the discussion that follows, I assume that private involvement does have certain advantages and that, at least in certain circumstances, the advantages of private involvement outweigh any potential disadvantages. This assumption is plausible for three reasons. First, eminent domain traditionally has been utilized for certain types of private takings, including assembling land for railroads, in which the holdout problem is particularly acute. See Kelly, 92 Cornell L Rev at 59-61 (cited in this note); Richard A. Posner, Foreword: A Political Court, 119 Harv L Rev 31, 93-94 (2004) (discussing use of eminent domain for "private firms, such as railroads and pipeline companies"). Second, even in situations in which the holdout problem is arguably less problematic, private parties may be more effective than the government at developing a previously assembled site. See Kelo v City of New London, 545 US 469, 486 (2005) (quoting Berman v Parker, 348 US 26, 33-34 (1954)). Third, under the current state of the law, almost all states, including most of the states that have enacted post-Kelo reforms, continue to permit private involvement in a number of circumstances. See generally Ilya Somin, The Limits of Backlash: Assessing the Political Response to Kelo, 93 Minn L Rev 2100, 2103-04 (2009) (reviewing post-Kelo legislation and concluding that "the majority of the newly enacted postKelo laws are likely to be ineffective" in preventing private takings).

${ }^{24}$ See Gideon Kanner, We Don't Have to Follow Any Stinkin' Planning-Sorry About That, Justice Stevens, 39 Urb Law 529, 537-38 (2007) (pointing out that "municipal functionaries are often unduly influenced or even controlled by private interests that, apart from instances of outright corruption, gain influence in city hall by means of political connections and campaign contributions, which are often the mother's milk of municipal politics"); Marc B. Mihaly, Living in the Past: The Kelo Court and Public-Private Economic Redevelopment, 34 Ecology L Q 1, 58 (2007) (asserting that 
who pay just compensation bear a relatively diffuse cost, private parties that benefit from the use of eminent domain obtain a relatively concentrated benefit. ${ }^{25}$ This concentrated benefit creates an incentive for parties to pursue the use of eminent domain even when a taking may not be consistent with the public interest. ${ }^{26} \mathrm{~A}$ condemnation process that avoids the appearance of corruption is also likely to be superior, all other things being equal, to a process that does not. ${ }^{27}$

Second, unlimited private involvement may lead to the problem of secondary rent seeking. If the value of several parcels as assembled is greater than the value of the parcels if fragmented, assembling the parcels through eminent domain creates a surplus. Assuming the condemnees receive fair market value (or even their subjective value) as just compensation, this surplus inures to the benefit of the condemnor. ${ }^{28}$ Yet, as Thomas Merrill has pointed out, "allocating the condemnation's entire surplus to the condemnor ... may produce a kind of secondary rent seeking of its own, as competing interest groups attempt to acquire or defeat a legislative grant of the power of eminent domain." ${ }^{29}$ Private efforts to capture eminent domain or oppose its use constitute a social waste, and, in certain circumstances, the costs of such efforts may exceed the benefits of the as-

\footnotetext{
"the process is in fact susceptible to corruption, a concern, however, that arises not so much from this public-private partnership as it does from the intrinsic role financial support of political candidates plays in the current electoral process"); Clayton P. Gillette, Kelo and the Local Political Process, 34 Hofstra L Rev 13, 16 (2005) (noting that a "big-box store owner, which expects to benefit from siting within the locality, will care a lot, enough to attempt to invest heavily in lobbying local officials to approve the condemnation" ${ }^{\prime}$; cf. Ellickson and Been, Land Use Controls at 308-09 (cited in note 23) (discussing corruption in land use planning)

${ }^{25}$ See Kelly, 92 Cornell L Rev at 34-35 (cited in note 23).

${ }^{26}$ See id at 37.

${ }^{27}$ See Richard Brooks, Kelo and the "Whaling City": A Search for the Urban Public Interest, 35 Real Est L J 223, 237 (2006) (noting that the "close relationship between public and private ... can also serve to delegitimize public urban development efforts if it is perceived to be merely an instrument of private interests"); cf. Buckley $v$ Valeo, 424 US 1, 27 (1976) ("Of almost equal concern as the danger of actual quid pro quo arrangements is the impact of the appearance of corruption stemming from public awareness of the opportunities for abuse inherent in a regime of large individual financial contributions.").

${ }^{28}$ See, for example, United States v Miller, 317 US 369, 375 (1943); see also David A. Dana, Reframing Eminent Domain: Unsupported Advocacy, Ambiguous Economics, and The Case for a New Public Use Test, 32 Vt L Rev 129, 139 (2007) (noting that, "in the case of covert assembly, landowners are also denied any of the value that may result from successful assembly").

${ }^{29}$ Merrill, 72 Cornell L Rev at 86 (cited in note 12); see also Gregory S. Alexander, Eminent Domain and Secondary Rent-Seeking, 1 NYU J L \& Liberty 958, 959 (2005) (defining secondary rent seeking as "efforts by interest groups to acquire (or defeat) a legislative grant of eminent domain" (citing Merrill)).
} 
sembly. ${ }^{30}$ Rent seeking is thus a distinct possibility whenever a private party expects to obtain all or a significant portion of a taking's surplus. ${ }^{31}$

Third, the possibility of private involvement in the condemnation process may lead private parties to threaten to relocate unless the local government condemns land on their behalf. Companies that provide towns or cities with substantial tax revenue and that are capable of moving to other locations know that such threats are credible. But these types of threats are problematic: they may pressure local officials to use eminent domain even though, in the absence of the threat, officials would not deem the taking to be in the public interest. Two examples from the cases illustrate this problem.

In Poletown Neighborhood Council v. City of Detroit,, General Motors Corporation (GM) threatened to relocate one of its factories if the City of Detroit did not provide a suitable site for a new factory. ${ }^{33}$ The City, concerned that GM might decide to build its factory elsewhere, agreed to condemn several hundred acres under the state's "quick take" statute. ${ }^{34}$ Although it analyzed nine different sites as possible options, the City ultimately selected Poletown, a residential neighborhood that matched all of GM's specifications. ${ }^{35}$ The rest

${ }^{30}$ See Henry A. Span, Public Choice Theory and the Political Utility of the Takings Clause, 40 Idaho L Rev 11, 50 (2003) (pointing out that "if the surplus produced by a government action can be distributed disproportionately, then people will waste resources trying to capture as much of this surplus as possible"); see also Nathan Burdsal, Note, Just Compensation and the Seller's Paradox, 20 BYU J Pub L 79, 90 (2005) (noting that "landowners engage in rent-seeking by trying to maximize the gain that they receive from society even when the gain creates social waste").

${ }^{31}$ See Merrill, 72 Cornell L Rev at 87 (cited in note 12) (noting that "eminent domain is most likely to foster secondary rent-seeking behavior ... where one or a small number of persons will capture a taking's surplus"); see also Nicole Stelle Garnett, The Neglected Political Economy of Eminent Domain, 105 Mich L Rev 101, 139 (2006) (pointing out "would-be beneficiaries of an economic development taking have a substantial incentive to engage in rent-seeking").

32304 NW2d 455 (Mich 1981) (per curiam), overruled by County of Wayne v. Hathcock, 684 NW2d 765 (Mich 2004).

${ }^{33}$ See id 460 (Fitzgerald dissenting) ("In the spring of 1980, General Motors Corporation informed the City of Detroit that it would close its Cadillac and Fisher Body plants located within the city in 1983. General Motors offered to build an assembly complex in the city, if a suitable site could be found."); see also Douglas W. Kmiec, Book Review, Property and Economic Liberty as Civil Rights: The Magisterial History of James W. Ely, Jr., 52 Vand L Rev 737, 758 (1999) (noting that the Poletown condemnations occurred "in order to avert General Motors' threatened partial departure from Detroit"I.

${ }^{34}$ Poletown Neighborhood Council, 304 NW2d at 461 (Fitzgerald dissenting).

${ }^{35} \mathrm{Id}$ at 460; see also Michael Heller and Rick Hills, Land Assembly Districts, 121 Harv L Rev 1465, 1510 (2008) (citing Bryan D. Jones and Lynn W. Bachelor, The Sustaining Hand: Community Leadership and Corporate Power 74-76 (U Press of Kansas, 1986)1. 
of the story is familiar: the Michigan Supreme Court approved the City's use of eminent domain, and thousands of people lost their homes and businesses, while the GM factory ultimately produced fewer jobs and less tax revenue than the City had projected. ${ }^{36}$

More recently, in 99 Cents Only Stores v. Lancaster Redevelopment Agency, ${ }^{37}$ Costco "threatened to relocate" one of its supermarkets unless the City of Lancaster provided it with additional retail space. ${ }^{38}$ Although the owner of the shopping center in which Costco leased its store had advised the City of Lancaster that Costco could expand behind 99 Cents Only, Costco "demanded" that it be allowed to expand directly into the adjacent site then occupied by 99 Cents. ${ }^{39}$ Lancaster, "fearful of Costco's relocation to another city," began negotiating with the shopping center's owner to purchase the lease for Costco's preferred parcel. ${ }^{40}$ When negotiations failed, the City authorized the condemnation of the lease ${ }^{41}$ Unlike in Poletown, the court held that the taking at issue was unconstitutional because "the very reason that Lancaster decided to condemn 99 Cents' leasehold interest was to appease Costco. ${ }^{\prime \prime 2}$

Overall, private involvement in the takings process entails a number of problems: the possibility of actual or perceived corruption, the existence of secondary rent seeking, and the issuance of threats to relocate. These problems suggest that private involvement may result in certain takings that advance a particular private interest but that are not necessarily in the public interest. If so, a rule allowing unlimited private involvement may be inferior to a rule allowing private involvement for certain types of takings but not others. In the analysis thus far, however, I have assumed that the process of identifying pretextual takings would be costless. In the next section, I relax this assumption.

\section{B. Problems with Pretextual Analysis}

The costs of permitting unlimited private involvement also can be viewed as the benefits of scrutinizing a taking for pretextual motivation. Yet a screening mechanism for pretext is only able to realize these benefits in an ideal world where a condemnor's motivation is

\footnotetext{
${ }^{36}$ See Somin, 15 S Ct Econ Rev at 194-95 (cited in note 4).

${ }^{37} 237$ F Supp 2d 1123 (CD Cal 2001).

${ }^{38}$ Id at 1126.

${ }^{39}$ Id.

${ }^{40} \mathrm{Id}$.

${ }^{41} \mathrm{Id}$.

${ }^{42} \mathrm{Id}$; see also id at 1129 ("No judicial deference is required . . . where the ostensible public use is demonstrably pretextual." (citing Armendariz v. Penman, 75 F3d 1311, 1321 (9th Cir 1996) (en banc)).
} 
immediately apparent. In reality, determining whether a taking is for a public purpose or whether the asserted purpose is a "mere pretext" for a private objective is extremely difficult. Here, I focus on three potential problems with considering motivation: disutility, futility, and administrability. ${ }^{43}$

Permitting courts to analyze pretext means that a court may strike down a governmental action because of its underlying motivation. ${ }^{44}$ As one might expect, an action that is invalidated on the basis of impermissible motivation is often detrimental to social welfare. However, an action may be invalidated on the basis of motivation even though the action itself is socially beneficial. The effect of invalidating a beneficial action solely on the basis of the underlying motivation is a loss of utility or "disutility."

It is easy see how the problem of disutility applies in the takings context. Evaluating whether a certain use of eminent domain is pretextual means that a taking might be invalidated even though a forced transfer would have increased social welfare. The Supreme Court seemingly has embraced this position in asserting that "it has long been accepted that the sovereign may not take the property of $A$ for the sole purpose of transferring it to another private party $B$, even though $A$ is paid just compensation. ${ }^{\prime 45}$ Under this doctrine, a taking whose purpose is to transfer a certain property to $B$ would be unconstitutional even if a local government could demonstrate with metaphysical certainty that $B$ valued the property more than $A$.

Allowing courts to analyze motivation also may lead to the problem of "futility." Futility refers to a court's inability to prevent governmental actions that are based on impermissible motivations because of the government's ability to circumvent judicial scrutiny. For example, government officials can hide their actual motivations, including pretextual ones. Moreover, even if a court detects an impermissible motivation and invalidates a governmental action on that basis, officials may decide to take the same action without dis-

${ }^{43}$ See generally John Hart Ely, Legislative and Administrative Motivation in Constitutional Law, 79 Yale L J 1205, 1212-17 (1970) (discussing these three problems).

${ }^{44}$ For present purposes, I use the terms "purpose," "motive," "intent," and "motivation" interchangeably, although I primarily use the term "motivation." See id at $1207 \mathrm{n} 1$ (noting that, while "purpose" and "motive" are terms more commonly used, motivation may have less connotative baggage); see also Lynda J. Oswald, Public Uses and Non-Uses: Sinister Schemes, Improper Motives, and Bad Faith in Eminent Domain Law, 35 BC Envtl Aff L Rev 45, 56, 58-61 (2008) (discussing the judicial use of the terms "motive," "purpose," and "motivation" in the condemnation context). But cf. Franco v Nat'l Capital Revitalization Corp, 930 A2d 160, 173 (DC 2007) ("The terms 'purpose, ' 'motive,' and 'intent' sometimes are used (imprecisely) as if they were interchangeable.").

${ }^{45} \mathrm{Kelo}, 545$ US at 477. 
closing their actual motivation, thereby circumventing the judicial test.

Again, it is easy to see how this problem of futility might arise in the takings context. Suppose that a development corporation approves a condemnation that provides a significant benefit to a particular developer. Local officials might attempt to hide their actual motivation-benefiting the developer-by asserting a pretextual justification such as increasing the city's tax revenue. ${ }^{46}$ But even if the officials reveal their true motivation, the condemnees seek injunctive relief, and the court holds that the asserted purpose is pretextual, the development corporation could simply approve the same condemnation without revealing the taking's actual purpose. If the condemnations are challenged again and if the court now upholds the takings, the court's original holding - that the condemnations were pretextual-turns out to be futile.

Perhaps even more troublesome is the problem of judicial administrability. Motivation, especially the motivation of government officials, is extremely difficult to establish..$^{47} \mathrm{~A}$ member of a state legislature does not necessarily reveal what is motivating a particular decision. Moreover, even when a legislator makes a statement that is indicative of her underlying motivation, that motivation may not be the same as the motivations of her fellow legislators. ${ }^{48}$

This administrability problem arises in the takings context as well. It is difficult to know the precise reason that a particular member of a development corporation votes to authorize the use of eminent domain. The member may genuinely believe that the development of a particular site will benefit the public. ${ }^{49}$ Alternatively, the member may favor a private interest that will profit from the project. Yet, even in the unlikely event that a development corporation member

${ }^{46} \mathrm{Cf}$. Oswald, 35 BC Envtl Aff L Rev at 61 (cited in note 44) (concluding that "even a condemnor, with clearly improper motives can, with a little effort and forethought, articulate a facially valid purpose for the taking and one which is relatively easy and relatively inexpensive to effectuate").

${ }^{47}$ See id at 58 ("Judicial reluctance to inquire into the motives underlying legislative actions (of any type, not just condemnations) is driven by the difficulty of assessing such motives.").

${ }^{48}$ See United States v O'Brien, 391 US 367, 384 (1968) (Warren, CJ) ("What motivates one legislator to make a speech about a statute is not necessarily what motivates scores of others to enact it, and the stakes are sufficiently high for us to eschew guesswork.").

${ }^{49} \mathrm{Cf}$. Somin, $15 \mathrm{~S}$ Ct Econ Rev at 239 (cited in note 4) (pointing out that local government officials who assert that public benefits are their true motivation "will not always be disingenuous" because "local government officials and the private interest groups they promote are likely to genuinely believe that policies that serve their political and economic self-interest also advance the public good"). 
declares her motivation, it is nearly impossible to know whether that member's motivation is representative of the other members' motivations..$^{50}$

Overall, while targeting pretext has a number of distinct benefits, ${ }^{51}$ it also involves several costs including the potential problems of disutility, futility, and administrability. A framework for analyzing pretext is only practicable (and, indeed, desirable) if these problems can be eliminated or, at least, mitigated. But if the issue ultimately is an empirical question that entails weighing the expected benefits and costs of private involvement, courts will continue to defer to condemnors even in those cases involving credible allegations of pretext. $^{52}$ The objective, then, is to design a test that captures the benefits of targeting pretext while avoiding the potential costs..$^{53}$

\section{DIFFICULTIES OF DESIGNING}

\section{A TEST}

\section{A. The Current Test Based on Kelo}

The current test for identifying whether a taking is "pretextual" is less than clear. Some courts have focused on the magnitude of the condemnation's projected public benefits. Other courts have investigated whether the taking is part of a comprehensive development plan or whether the condemnor satisfies certain procedural requirements. Still others have examined whether the potential private

\footnotetext{
${ }^{50}$ Cf. Goldstein v Pataki, 516 F3d 50, 63 (2d Cir 2008) ("Beyond being conclusory, the claim that the 'decision to take Plaintiffs' properties serves only one purpose' defies both logic and experience. 'Legislative decisions to invoke the power to condemn are by their nature political accommodations of competing concerns.'" (quoting Brody $v$ Village. of Port Chester, 434 F3d 121, 136 (2d Cir 2005)).

${ }^{51}$ See Part II(A).

${ }^{52}$ See Kelo, 545 US at 483 ("For more than a century, our public use jurisprudence has wisely eschewed rigid formulas and intrusive scrutiny in favor of affording legislatures broad latitude in determining what public needs justify the use of the takings power."); id at 503 (O'Connor dissenting) ("The Court rightfully admits . . that the judiciary cannot get bogged down in predictive judgments about whether the public will actually be better off after a property transfer." |; see also Goldstein, 516 F3d at 64-65 ("At the end of the day, we are left with the distinct impression that the lawsuit is animated by concerns about the wisdom of the Atlantic Yards Project and its effect on the community.... [S] uch matters of policy are the province of the elected branches, not this Court.").

${ }^{53}$ For a contrary approach in which the proper scope of private involvement is determined through negotiations between public agencies and private developers, see Mihaly, 34 Ecology L Q at 40-41 (cited in note 24) ("Public-private negotiations strive to determine the most efficient actors for each development function at each stage in the life of a project.").
} 
beneficiaries are identifiable at the time of the development plan's adoption. Because these three factors-the magnitude of public benefits, the extensiveness of government planning and process, and the identification of private beneficiaries-are the primary factors discussed in the majority and concurring opinions in Kelo, as well as in the subsequent case law, I discuss each of them in turn.

\section{Magnitude of Public Benefits}

While the Court itself did not mention whether the magnitude of public benefits is relevant for identifying pretext, Justice Kennedy's concurrence emphasized that "[a] court applying rational-basis review under the Public Use Clause should strike down a taking that, by a clear showing, is intended to favor a particular private party, with only incidental or pretextual public benefits. ${ }^{\prime \prime 4}$ Kennedy also noted that one of the reasons that the condemnations at issue in Kelo were not subject to a more demanding level of scrutiny was that "the projected economic benefits of the project cannot be characterized as de minimis. ${ }^{\prime \prime 5}$ Unfortunately, Kennedy did not provide any criterion by which to determine whether a taking's benefits are "incidental" or "de minimis." As an initial matter, therefore, it is unclear what the threshold is for declaring that a condemnation's public benefits are so small that the condemnation itself is pretextual. ${ }^{56}$

Nevertheless, several post-Kelo decisions have focused on the magnitude of public benefits as an important, and perhaps decisive, factor. ${ }^{57}$ In Franco v. National Capital Revitalization Corporation, the

${ }^{54}$ Kelo v City of New London, 545 US 469, 491 (2005) (Kennedy concurring) (emphasis added); see also id. ("As the trial court in this case was correct to observe, 'Where the purpose [of a taking] is economic development and that development is to be carried out by private parties or private parties will be benefited, the court must decide if the stated public purpose-economic advantage to a city sorely in need of it—is only incidental to the benefits that will be confined on private parties of a development plan.'" (quoting App to Pet for Cert 263) (emphasis added)).

${ }^{55} \mathrm{Id}$ at 493.

${ }^{56}$ This ambiguity is amplified because, by using the phrase "incidental or pretextual benefits," id at 491 (emphasis added), Kennedy appears to be making a distinction between incidental benefits and pretextual benefits. Such a distinction might imply that a taking could result in incidental benefits that are not pretextual or, alternatively, pretextual benefits that are not incidental.

${ }^{57}$ See, for example, Franco v Nat'l Capital Revitalization Corp, 930 A2d 160, 173-74 (DC 2007); see also Goldstein v Pataki, 516 F3d 50, 58 (2d Cir 2008) ("[T]he instant complaint calls the 'alleged "public benefits" ... either wildly exaggerated or simply false. At best, [they] are incidental; at worst, they are nonexistent.' Read carefully, however, the specific allegations in the complaint foreclose any blanket suggestion that the Project can be expected to result in no benefits to the public." (second alteration in original)). 
District of Columbia's development corporation initiated condemnation proceedings against Samuel Franco, the owner of a "Discount Mart" store.$^{58}$ In analyzing Franco's defenses, the court explained that "Kelo makes clear that there is room for a landowner to claim that the legislature's declaration of a public purpose is a pretext designed to mask a taking for private purposes. ${ }^{\prime 59}$ Ultimately, the D.C. Court of Appeals held that "Franco adequately pled such a defense" ${ }^{\prime 60}$ and thus remanded the case to the trial court. ${ }^{61}$ In remanding the case, the court endorsed Justice Kennedy's emphasis on the magnitude of public benefits and also proposed a distinction between "substantial" and "incidental" benefits. ${ }^{62}$ But, like Kennedy, the court did not offer any criterion for determining whether benefits are "substantial" or "incidental" or for evaluating the "[h]arder cases" that lie "between these extremes." ${ }^{\prime \prime 3}$

In theory, a test that relied on the magnitude of public benefits could be useful. If the public benefits of a taking were relatively large, then a court might conclude that such benefits outweigh the risk of impermissible favoritism. Suppose, for example, that an independent analyst estimated that the public benefits of a condemnation would include 500 new jobs, $\$ 4$ million in additional tax revenue, and 200 units of affordable housing. The court might conclude that, notwithstanding the possibility that the actual purpose of the taking may be to benefit a private developer, the magnitude of the public benefits justifies private involvement. Alternatively, if the public benefits of a taking were relatively small, then a court might conclude that the risk of favoritism outweighs any potential public benefits. Suppose, for example, that an analyst estimated that the public benefits of a condemnation would include 5 new jobs, $\$ 40,000$ in tax revenue, and 2 units of affordable housing. The court might conclude that,

${ }^{58} 930 \mathrm{~A} 2 \mathrm{~d}$ at 162. Four private corporations had prepared a plan to redevelop the site into a "first-class, quality mixed-use retail center," id at 163, and a committee of the D.C. Council approved findings that the existing shopping center was a "blighting factor," id. Franco raised a number of defenses and counterclaims including a defense that "the declared reason for the taking was pretextual and that the true purpose was to confer a private benefit on a particular private party." Id at 164 .

${ }^{59}$ Id at 171.

${ }^{60}$ Id at 172 .

${ }^{61}$ Id at 176.

${ }^{62}$ Id at 173-74 ("We conclude that a reviewing court must focus primarily on benefits the public hopes to realize from the proposed taking. If the property is being transferred to another private party, and the benefits to the public are only 'incidental' or 'pretextual,' a 'pretext defense may well succeed.' On the other hand, if the record discloses (in the words of the trial court) that the taking will serve 'an overriding public purpose' and that the proposed development 'will provide substantial benefits to the public,' the courts must defer to the judgment of the legislature.").

${ }^{63}$ Id at 174. 
notwithstanding these benefits, private involvement is not justified because of the countervailing risk that the taking's asserted purpose is pretextual. The only question then would be distinguishing between public benefits that are "substantial" and those that are "incidental."

The public benefits test, however, suffers from several additional shortcomings. By focusing only on the magnitude of public benefits, the test seems to ignore the magnitude of private benefits. Yet private benefits seem relevant. Suppose that an assembly project is expected to add 50 new jobs, $\$ 400,000$ in tax revenue, and 20 units of affordable housing. If landowners challenged the local government's use of eminent domain to assemble the land, a court might reject a pretext defense if the private developer was expected to obtain a benefit of only $\$ 10,000$. However, a court could, and probably should, view the case differently if the developer was expected to obtain a benefit of $\$ 1$ million. But neither Justice Stevens nor Justice Kennedy mentions the magnitude of private benefits as a potential factor. As a result, two takings with the same expected public benefits presumably would be judged similarly even though they differ dramatically with regard to the expected private benefits.

Perhaps an even more fundamental problem with the public benefits test is that the test relies on "projected" public benefits. In Kelo, Justice Kennedy focused on the fact that the "projected economic benefits of the project cannot be characterized as de minimis." "64 Likewise, in Franco, the D.C. Court of Appeals emphasized that "a reviewing court must focus primarily on the benefits the public hopes to realize from the proposed taking. ${ }^{\prime \prime 5} \mathrm{~A}$ test based on projected benefits is likely to prove vacuous in most circumstances. Not only is it extremely difficult to estimate a project's expected benefits, ${ }^{66}$ but both the condemnor and the private beneficiaries of a condemnation have an incentive to inflate projected benefits to insulate the condemnation from scrutiny. ${ }^{67}$ Consequently, for almost any assembly

${ }^{64} 545$ US at 491 (Kennedy concurring) (emphasis added).

${ }^{65} 930$ A2d at 173-74 (emphasis added).

${ }^{66}$ See Somin, 15 S Ct Econ Rev at 202 (cited in note 4) (pointing out that "the calculation of the costs and benefits of most development projects is extremely complex"); Garnett, 105 Mich L Rev at 139 (cited in note 31) ("Determining the 'efficiency' ... of any project enabled by eminent domain is difficult at best, given the multiplicity of a project's possible costs and benefits, the length of the relevant time horizons, and so on.").

${ }^{67}$ See Somin, 15 S Ct Econ Rev at 197 (cited in note 4) (asserting that "nothing prevents municipalities and private interests from using inflated estimates of economic benefits to justify condemnations"); Kelly, 92 Cornell L Rev at 28 (cited in note 23) (pointing out that private parties may "intentionally exaggerate the expected benefits of a taking for the purpose of obtaining the state's condemnation authority"); see 
project, local officials could provide an estimate that purports to demonstrate the potential for significant public benefits. ${ }^{68}$

Indeed, to rely on a test based on the magnitude of projected public benefits (or even the anticipated ratio of public to private benefits) makes little sense in light of the Supreme Court's explicit rejection of a "reasonable certainty" requirement in Kelo. The petitioners in Kelo argued that, in examining economic development takings, the Court should "require a 'reasonable certainty' that the expected public benefits will actually accrue. ${ }^{\prime 69}$ In rejecting this argument, the Court noted that such a rule would represent a departure from precedent, particularly the Court's admonition in Hawaii Housing Authority V. Midkiff ${ }^{70}$ that federal courts are not the appropriate place for empirical debates about the wisdom of takings. ${ }^{71}$ In light of the Court's own skepticism regarding a reasonable certainty requirement, evaluating pretext by relying on a factor that requires a judicial determination of expected benefits seems problematic. ${ }^{72}$

also Gillette, 34 Hofstra L Rev at 20 (cited in note 24) (describing the government's "incentive for undue optimism" because "there is little reason for local officials not to forecast the financially rosiest of futures for those parcels, since doing so gains political support for the project, allowing them to take credit for what is described as the impending economic boom"

${ }^{68}$ See Kelo, 545 US at 504 (O'Connor dissenting) (contending that neither the Court's rule nor Justice Kennedy's "gloss" on that rule is a meaningful restraint on private takings "[i]f legislative prognostications about the secondary public benefits of a new use can legitimate a taking" |; cf. Supreme Court 2004 Term, Leading Cases, Public Use-Economic Development, 119 Harv L Rev 287, 294 (2005) (asserting that the majority's test is "unlikely to have much bite: a reasonably creative legislator will almost always be able to tell a story that connects a given taking with a projected public benefit, particularly when a court will defer to her characterization of a purpose as public").

${ }^{69}$ Kelo, 545 US at 487; see also Brief of Petitioners, Kelo v City of New London, Civil Action No 04-108, *36 (US filed Dec 3, 2004) (available on Westlaw at 2004 WL 2811059) ("The condemnation of property for economic development projects should only occur if and when the government can show that there is reasonable certainty that the project will proceed and yield the public benefits that are used to justify the condemnation.").

${ }^{70} 467$ US 229 (1984).

${ }^{71}$ See Kelo, 545 US at 488 ("When the legislature's purpose is legitimate and its means are not irrational, our cases make clear that empirical debates over the wisdom of takings-no less than debates over the wisdom of other kinds of socioeconomic legislation-are not to be carried out in the federal courts." (quoting Midkiff, 467 US at 242-43)|; see also George Lefcoe, Redevelopment Takings After Kelo: What's Blight Got to Do With It?, 17 S Cal Rev L \& Soc Just 803, 812 (2008) ("The Court will not hear arguments that the plan's means are unlikely to lead to the plan's stated goals, or even that the goals are unrealistic and unattainable." (citing Kelo, 545 US at 488)).

${ }^{72} \mathrm{Cf}$. Mahoney, 2005 Sup Ct Rev at 117-18 (cited in note 7) ("This last statementexpressing confidence that courts will be able to readily identify takings that have no 
The ultimate problem with a test based on the magnitude of projected public benefits is thus one of administrability. It is extremely difficult for a court to estimate the projected public benefits of a proposed taking. It is also extremely difficult for a court to estimate the potential private benefits of a proposed taking. Relying on these types of projections, therefore, fails to provide an effective safeguard for ensuring that a local government's asserted purpose is not pretextual.

\section{Extensiveness of Planning and Process}

Although not mentioning the public benefits factor, the majority opinion in Kelo did emphasize the importance of "planning" in evaluating whether a taking is pretextual. The Court directly juxtaposed pretext and planning. It concluded that, while New London would not be allowed to take property under the "mere pretext" of a public purpose, the takings at issue "would be executed pursuant to a 'carefully considered' development plan."173 The Court also noted that, while not presented in this case, "a one-to-one transfer of property, executed outside the confines of an integrated development plan, ... would certainly raise a suspicion that a private purpose was afoot ...." ."74 Similarly, in his concurring opinion, Justice Kennedy asserted that one of the reasons that a more demanding standard of review was unnecessary was that the condemnations "occurred in the context of a comprehensive development plan ...." ${ }^{\prime 75}$ In a recent article examining Kelo's emphasis on planning, Nicole Garnett points out that the majority and concurring opinions mention the words "plan" or "planning" nearly fifty times. ${ }^{76}$

The existence of a development plan has been relevant in several post-Kelo cases. ${ }^{77}$ Perhaps most notably, in Didden v. Village

conceivable public purpose other than to generate additional taxes-to some degree undermines the earlier claim that there is no practicable way to distinguish economic development takings from other exercises of the eminent domain power.").

${ }^{73}$ Kelo, 545 US at 478 (quoting Kelo v City of New London, 843 A2d 500, 536 (Conn. 2004) (emphasis added)).

${ }^{74} \mathrm{Id}$ at 487 (emphasis added).

${ }^{75}$ Id at 493 (Kennedy concurring) (emphasis added).

${ }^{76}$ See Nicole Garnett, Planning as Public Use?, 34 Ecology L Q 443, 444 (2007) ("The Kelo majority mentioned the words 'plan' or 'planning' forty times; Justice Kennedy's separate opinion brought the tally to nearly fifty.").

${ }^{77}$ Compare Mayor 4 City Council of Baltimore City v Valsamaki, 916 A2d 324, 351-52 \& n 26 (Md 2007) (invalidating quick-take condemnation because, inter alia, city had "no plan for the development of the Property") with W. Seafood Co. v United States, 2006 US App LEXIS 25520, *13, 2006 WL 2920809, ** 4 (5th Cir 2006) ("The proposed taking of Western Seafood's property is the result of a carefully considered 
of Port Chester, ${ }^{78}$ storeowner Bart Didden and several landowners (collectively, the "Plaintiffs") sued Port Chester and several Private Defendants, including the Village's preferred developer, to prevent the use of eminent domain for a redevelopment project. ${ }^{79}$ The Plaintiffs alleged that the "Private Defendants demanded that Plaintiffs either pay them $\$ 800,000$ or give them a partnership interest in the project or Private Defendants would cause Port Chester to commence a condemnation proceeding" against their property. ${ }^{80}$ The district court held that Plaintiffs' primary claims were time-barred but that, in any event, the "allegation of an extortionate demand of $\$ 800,000$ to avoid condemnation adds nothing of legal significance to Plaintiffs' claims. ${ }^{\prime \prime 1}$ On appeal, the Second Circuit concluded that, even if Plaintiffs' claims were not time-barred, Kelo precludes these claims "to the extent that they assert that the Takings Clause prevents the State from condemning their property for a private use within a redevelopment district .... ${ }^{\prime \prime 2}$ The court appeared to be suggesting that, because these condemnations had occurred within a "redevelopment district," Kelo effectively insulates the takings from a public use challenge. ${ }^{83}$

development plan."). But cf. MiPro Homes, L.L.C. v Mount Laurel Twp, 878 A2d 38, 44 (NJ Super 2005) (concluding that a municipality may exercise authority to condemn property for open space "even though it does not presently have a plan to devote the property to active recreational uses"), aff'd 910 A2d 617 (NJ 2006) (per curiam).

${ }^{78} 304$ F Supp 2d 548 (SDNY 2004), aff'd 2006 US App LEXIS 8653, 2006 WL 898093 (2d Cir 2006).

${ }^{79} \mathrm{Id}$ at 551.

${ }^{80} \mathrm{Id}$ at 556 . The court initially denied Plaintiffs' motion for a preliminary injunction and concluded that Plaintiffs were not likely to prevail on their takings claim. See id at 559. The court asserted that, because the redevelopment project "serves a clear public purpose-the redevelopment of the blighted downtown area of Port Chester," the "alleged 'bribe' by Private Defendants, even if it was a 'bad faith' offer, could not in any way have transformed that public purpose into a private purpose." Id. The court also noted that it could not "get involved in parsing the particular degree of public or private motivation behind the inclusion of a particular site in the Project area, so long as that inclusion could rationally be related to the public purpose of the plan as a whole." Id (quoting Rosenthal ↔) Rosenthal Inc v New York State Urban Development Corp, 605 F Supp 612 (SDNY), aff'd, 771 F2d 44, 45 (2d Cir 1985)).

${ }^{81}$ Didden $v$ Village of Port Chester, 322 F Supp 2d 385, 390 (SDNY 2004).

${ }^{82}$ Didden, 2006 US App LEXIS 8653, *4-5, 2006 WL 898093, **2.

${ }^{83}$ See Amicus Brief of Law Professors D. Benjamin Barros, et al, Didden v Village of Port Chester, Civil Action No 06-652, * 4 (US filed Dec 8, 2006) (available on Westlaw at 2006 WL 3610985) ("Law Professors Amicus Brief") ("If the Court allows clearly pretextual condemnations to go forward merely because they occur within a redevelopment area, then the proliferation of these areas will open the door to widespread abuses of political power."); cf. Garnett, 34 Ecology L Q at 453-54 (cited in note 76) (concluding that "the majority opinion in Kelo and Justice Kennedy's concurrence suggest that planning almost always precludes a finding of pretext" and that "it is fairly clear that Kelo proceeds on the assumption that planning and pretext are usually incompatible"). 
In theory, an emphasis on planning might reduce the number of pretextual takings. Planning might act as a filtering mechanism. By requiring local officials and private developers to engage in a certain level of planning, the public might obtain more information about the assembly and thus be more likely to identify a taking as pretextual. Planning also might act as a deterrent mechanism. If local officials and private developers know that condemnations must occur within development plans and that the public is able to scrutinize these plans, they may hesitate before proposing projects that are not in the public interest. Furthermore, even if planning does not help to identify or deter pretextual takings, planning might increase the costs of relying on eminent domain. These costs may cause local governments to rely on eminent domain less frequently in assembling land on behalf of private developers. ${ }^{84}$

Ultimately, planning is unlikely to provide an adequate test for identifying pretext. Planning's primary effect is on the timing of the condemnations rather than the type of condemnations. Extensive planning increases the length of the process. ${ }^{85}$ However, while a longer process may provide property owners more time to organize politically, ${ }^{86}$ it does not necessarily provide a mechanism for distinguishing between legitimate and pretextual takings. Moreover, if planning did disclose that a taking was pretextual, it is doubtful that the sanction imposed on a private party, if any, would be significant. Planning is thus unlikely to deter firms who are willing to threaten local officials with the possibility of relocating. Finally, although planning does increase an assembly's costs, higher costs may not diminish a taking's private benefits to such an extent that private developers would abandon their efforts to acquire eminent domain. Indeed, because planning costs usually will be borne by the government, not the developers themselves, ${ }^{87}$ a planning requirement may not deter developers from seeking eminent domain for their own objectives.

${ }^{84}$ See Amicus Brief of the American Planning Association, et al, Kelo v. City of NeW London, Civil Action No 04-108, *26 (US filed Jan 21, 2005) (available on Westlaw at 2005 WL 166929) ("APA Amicus Brief") ("To the extent the need to undertake a planning process including public participation magnifies the cost differential between eminent domain and market transactions, these processes also provide a further disincentive to use eminent domain.").

${ }^{85}$ See Garnett, 34 Ecology L Q at 460 (cited in note 76) ("Planning takes time....").

${ }^{86} \mathrm{See}$ id. (pointing out that "the planning process may give property owners (and especially homeowners) an opportunity to organize so as to protect their interests").

${ }^{87}$ See Mihaly, 34 Ecology L Q at 57 (cited in note 24) (pointing out that for publicprivate redevelopment projects "the city might contribute ... the land either for free or at below market value"); Kelly, 92 Cornell L Rev at 37 (cited in note 23) (noting that private parties who benefit from the use of eminent domain are "usually not required to pay any compensation to either the condemnees or the state" and discussing several examples where acquisition costs were nominal). 
In any event, while additional costs may decrease the government's reliance on eminent domain, they do not help to distinguish between situations in which private involvement is necessary and situations in which it may be pretextual. ${ }^{88}$

In addition to emphasizing planning, Justice Kennedy focused on the related issue of the condemnor's compliance with eminent domain's procedural requirements. Kennedy noted that New London had "complied with elaborate procedural requirements that facilitate review of the record and inquiry into the city's purposes. ${ }^{\prime 89}$ While enforcing procedural requirements does increase the costs of eminent domain and thereby encourages reliance on market exchange, ${ }^{90}$ procedure, like planning, does not provide a mechanism for distinguishing between takings in which private involvement is legitimate and takings in which private involvement is pretextual. Indeed, pro-

${ }^{88}$ The case law presents two doctrinal complications with relying on planning as well. First, although the Supreme Court cited 99 Cents Only as being problematic because of the absence of planning, the condemnation in 99 Cents Only actually did occur pursuant to a development plan. See note 4 (citing 99 Cents Only Stores v Lancaster Redevelopment Agency, 237 F Supp 2d 1123, 1125 (CD Cal 2001)). The Court's citation to 99 Cents Only raises the question of whether all condemnations within a plan are incompatible with a finding of pretext or only a subset of condemnations within a plan; alternatively, the Court's concern with the type of condemnation at issue in 99 Cents Only may have been less about the existence of a development plan and more about the fact that the taking was "a one-to-one transfer of property." Id; see also Part V(B)|(6) (discussing one-to-one takings). Second, if a development plan is indeed all that is required to immunize a taking from being evaluated for a pretextual motivation, then planning could create a zone free from judicial review. Petitioners in Didden pointed out this apparent anomaly in seeking to persuade the Supreme Court to issue a writ of certiorari. See Petition for Certiorari, Didden v Village of Port Chester, Civil Action No 06-652, * 10 (US filed Nov 7, 2006) (available on Westlaw at 2006 WL 3265594) ("If the Second Circuit's interpretation is allowed to stand, it will effectively insulate condemnations in redevelopment areas from judicial review."); see also supra note 83 .

${ }^{89} \mathrm{Kelo}, 545$ US at 493. Here, Justice Kennedy seemed to be adopting an argument from the American Planning Association's amicus brief, which Thomas Merrill and John Echeverria co-authored. See APA Amicus Brief, ${ }^{\star} 24$ (cited in note 84). In their brief, Merrill and Echeverria point out that "[e]minent domain is generally more expensive [than market purchase] because the power is cabined by a variety of procedural requirements that entail significant cost and delay for agencies seeking to acquire resources." Id. They thus suggest that "the most constructive contribution courts can make in protecting against misuse or overuse of eminent domain is to insist that the procedural requirements associated with the exercise of eminent domain be faithfully followed in every case." Id at 25; see also David A. Dana \& Thomas W. Merrill, Property: Takings 206 (Foundation Press, 2002) ("In effect, the imposition of the due process tax makes the exercise of eminent domain largely self-regulating: It will be used only where the surplus to the taker is greater than the due process tax.").

${ }^{90}$ See notes 12 \& 84; see also APA Amicus Brief at ${ }^{\star} 25$ (cited in note 84) ("Strict enforcement of procedural requirements ... makes eminent domain largely selfregulating, in the sense that it will only be used in situations where the costs of negotiated exchange are prohibitive."). 
cedural regularity is an imperfect proxy for the absence of pretext because, even assuming that due process costs would be borne by private developers (rather than local governments), developers may be willing to bear significant due process costs to obtain windfall benefits. Conversely, procedural irregularity is an imperfect proxy for the presence of pretext because a deficiency in process does not necessarily mean that the taking itself is pretextual. ${ }^{91}$

The ultimate problem with relying on planning or process is thus one of futility. A local government that wishes to use the power of eminent domain on behalf of a private developer can easily do so, even if the taking is pretextual, simply by incorporating the taking into a comprehensive development plan and following the requisite procedural requirements. ${ }^{92}$ Moreover, if a court invalidates a taking based on a lack of planning or a deficiency in procedure, local officials can accomplish the same objective simply by reauthorizing the condemnation within a more comprehensive development plan or using more stringent procedural requirements. ${ }^{93}$ Likewise, while planning and procedural requirements do increase the costs of eminent domain, these requirements may be futile if a private developer (or the local government on behalf of a developer) is still willing to pay these costs to obtain the resulting private benefits.

\section{Identification of Private Parties}

Justice Stevens and Justice Kennedy both suggested that the condemnations at issue in Kelo were not pretextual for an additional reason: the identities of the private beneficiaries were not known until after the development plan was adopted. Stevens asserted that it is "difficult to accuse the government of having taken $A$ 's property to benefit the private interests of $B$ when the identity of $B$ was unknown. ${ }^{\prime \prime 4}$

${ }^{91}$ Cf. Whren v United States, 517 US 806, 816 (1996) (noting that "it is a long leap from the proposition that following regular procedures is some evidence of lack of pretext to the proposition that failure to follow regular procedures proves (or is an operational substitute for) pretext").

${ }^{92}$ See Kelo, 545 US at 502 (O'Connor dissenting) ("Whatever the details of Justice Kennedy's as-yet-undisclosed test, it is difficult to envision anyone but the 'stupid staff[er]' failing it." (citing Lucas $v$ South Carolina Coastal Council, 505 US 1003, 1025-26 n 12 (1992) (alteration in Kelo))).

${ }^{93} \mathrm{Cf}$. Somin, $15 \mathrm{~S}$ Ct Econ Rev at 236 (cited in note 4) ("Even if the jurisdiction in question did not initially intend to adopt a plan, after Kelo, it would surely choose to do so in order to insulate itself from legal challenge.").

${ }^{94}$ Kelo, 545 US at 478 n 6; see also id (explaining that "while the City intends to transfer certain of the parcels to a private developer in a long-term lease-which developer, in turn, is expected to lease the office space and so forth to other private tenants-the identities of those private parties were not known when the plan was adopted"I. 
Likewise, Kennedy pointed out that the trial court had considered testimony indicating that "the substantial commitment of public funds by the State to the development project [had occurred] before most of the private beneficiaries were known" and that "the other private beneficiaries of the project are still unknown because the office space proposed to be built has not yet been rented. ${ }^{\prime \prime 95}$ Kennedy also maintained that a more demanding level of scrutiny was unnecessary because "[ $\mathrm{t}]$ he identities of most of the private beneficiaries [we]re unknown at the time the city formulated its plans." ${ }^{\prime \prime 6}$

However, a recent case from the Second Circuit, Goldstein v. Pataki, ${ }^{97}$ suggests that lower courts may not believe that the timing of the identification of private parties is decisive. Goldstein involved the Atlantic Yards Arena and Redevelopment Project, a twenty-two acre, multibillion dollar assembly in downtown Brooklyn. ${ }^{98}$ Plaintiffs, fifteen property owners, contended that Bruce Ratner, the project's primary developer, and his development firm, Forest City Ratner Companies, were the actual impetus behind the project. ${ }^{99}$ On appeal, the Second Circuit noted that the "sequence of events was certainly one of the factors considered in Kelo" and also observed that, "unlike in Kelo, the Atlantic Yards Project was allegedly proposed in the first instance by Ratner himself." ${ }^{100}$ Yet the court, quoting a New York state case, quickly dismissed this concern and asserted that "New York long ago decided by statute not to restrict [a development corporation's] mandate to those 'projects in which it is the prime

${ }^{95}$ Id at 491-92 (Kennedy concurring).

${ }^{96} \mathrm{Id}$ at 493 . The timing concerning the identification of private parties is actually somewhat complicated in Kelo. Plaintiffs alleged that the project's primary beneficiary was not the developer who would lease the assembled land or other private parties who might rent office space but rather Pfizer Corporation, which recently opened a global research facility nearby. The Court asserted that the New London Development Corporation (NLDC) intended for the development plan "to capitalize on the arrival of the Pfizer facility and the new commerce it was expected to attract." Id at 474 . The dissenters viewed the relationship differently, noting that the city council approved the NLDC's development plan just two months after Pfizer had announced that it would build its new facility. See id at 495 ( $\mathrm{O}^{\prime}$ Connor dissenting).

${ }^{97} 516$ F3d 50 (2d Cir 2008).

${ }^{98} \mathrm{Id}$ at 53 . Plans for the site include a new professional basketball stadium, sixteen high-rise apartment towers, several office towers, and the creation of a public open space. Id.

${ }^{99}$ Id at 55-56. Specifically, plaintiffs alleged "that [Ratner], not a state agency, first conceived of developing Atlantic Yards, that the Ratner Group proposed the geographic boundaries of the Project, and that it was [Ratner's] plan for the Project that the ESDC [Empire State Development Corporation] eventually adopted without significant modification." Id.

${ }^{100}$ Id at 64. 
mover. '" ${ }^{\prime 101}$ If Kelo's discussion of pretext is based on federal constitutional law, it is unclear why a New York state decision, interpreting New York law, would have any effect on the analysis. ${ }^{102}$ In any event, the court did not seem bothered by the sequence of events and ultimately rejected the plaintiffs' allegations of pretext. ${ }^{103}$

The intuition behind relying on the timing of the identification of private parties is relatively straightforward. If a private party's identity is unknown at the time of a development plan's adoption, it is unlikely that the private party is the impetus behind the project. On the other hand, if a private party's identity is known at the time of a development plan's adoption, it is possible that the private party is the impetus behind the project. The Court's emphasis on the identification of private parties is thus a plausible criterion by which to judge whether a taking's asserted purpose is a pretextual one. Moreover, if lower courts actually were to apply this factor, it may be more difficult for private developers to demand that local governments condemn particular sites as public-private coordination would be possible only after the adoption of a development plan.

The problem with this factor, however, is that it is potentially both underinclusive and overinclusive. It is sometimes unnecessary, even after the development plan is known, to rely on a particular preferred developer. Under these circumstances, if the government selects a preferred developer, it creates the possibility of impermissible favoritism. This factor is thus potentially underinclusive. On the other hand, it may sometimes be necessary, even before the adoption of the development plan, to rely on a particular private developer. ${ }^{104}$ Indeed, in certain situations, a private developer may have information that local officials do not have regarding the appropriate

\footnotetext{
${ }^{101}$ Id (quoting E Thirteenth St Cmty Ass'n v NY State Hous Fin Agency, 218 AD2d 512, 513 (NY App Div 1st Dep't 1995)).

${ }^{102}$ But cf. Franco, 930 A2d at 175 (asserting that "nothing in Kelo suggests that the items of evidence mentioned there set constitutional standards").

${ }^{103}$ See Goldstein, 516 F3d at 65. By contrast, in Franco, the District of Columbia Court of Appeals explicitly credited plaintiff's allegation that the revitalization corporation entered into a joint development agreement with a private developer two years before the introduction of the first bill concerning the assembly. 930 A2d at 170-71.

${ }^{104} \mathrm{Cf}$. Lefcoe, 17 S Cal Rev L \& Soc Just at 811 (cited in note 71 ) (pointing out, as a descriptive matter, that "most redevelopment authorities work closely with consultants and private developers to identify private market users before acquiring land for redevelopment"); Mihaly, 34 Ecology L Q at 57-58 (cited in note 24) (asserting, as a normative matter, that Justice Kennedy's focus on "the timing of the identification of the private beneficiaries" is problematic because "it may be of financial and strategic advantage to the public to have a master developer involved in the economic and physical planning of the site well before site acquisition is complete").
} 
site for an assembly project. As a result, this factor is potentially overinclusive as well.

Ultimately, the problem with relying exclusively on the timing of the identification of private parties is one of disutility. This factor may permit certain takings involving post-condemnation private involvement by particular developers even where such involvement is unnecessary. Conversely, this factor may prohibit certain takings involving pre-condemnation private involvement even where such involvement may be necessary.

\section{B. An Alternative Test Based on Intent}

If the current framework is problematic, it is appropriate to consider alternative tests. One obvious possibility is to focus exclusively on the condemnor's intent. In an ideal world in which motivation is perfectly observable, the test would be simple. If the condemnor asserts a public purpose for a taking and the condemnor's asserted purpose for the taking is the actual purpose, then the condemnation is not pretextual. If the condemnor's asserted purpose for the taking is not the actual purpose, and the actual purpose is to bestow a benefit on a private party, then the condemnation is pretextual. ${ }^{105}$

However, a test based exclusively on a condemnor's motivation is problematic for several reasons. As an initial matter, a condemnation that is invalidated merely on the basis of the condemnor's intent may result in a social loss if the project is, in fact, welfareenhancing. ${ }^{106}$ Moreover, because a condemnor usually does not disclose what is motivating a particular decision, a test based on intent may be futile. ${ }^{107}$ Finally, because the condemnor's actual motivation is relatively difficult to determine, the test may not be judicially administrable. ${ }^{108}$

${ }^{105}$ See, for example, Middletown Twp v Lands of Stone, 939 A2d 331, 337 (Pa 2007) ("In considering whether a primary public purpose was properly invoked, this Court has looked for the 'real or fundamental purpose' behind a taking. Stated otherwise, the true purpose must primarily benefit the public." (citation omitted)); see also Oswald, 35 BC Envtl Aff L Rev at 61 (cited in note 44) ("Some courts have ... tried to address the issue by examining whether the purpose articulated by the condemnor is a real one, or is just a sham. This leads the court into convoluted issues of true versus stated purpose and raises the ill-defined role of bad faith in takings analysis."). Below, I consider another possibility: that the asserted purpose for the taking is not the actual purpose for the taking but the actual purpose is not to bestow a benefit on a private party. See Part $\mathrm{V}(\mathrm{B})(7)$. While such a scenario is likely to arise rather infrequently, it is a possibility if the condemnor's objective is to target a disfavored party rather than to benefit a favored party. See id.

${ }^{106}$ See Part II(B) (describing problem of "disutility").

${ }^{107}$ See id (describing problem of "futility").

${ }^{108}$ See id (describing problem of "administrability"). 
In practice, courts have been quite reluctant to investigate the underlying motivations of state legislators and local officials who authorize and exercise the eminent domain power. ${ }^{109}$ As the Second Circuit recently emphasized: "We do not read Kelo's reference to 'pretext' as demanding ... a full judicial inquiry into the subjective motivation of every official who supported the Project, an exercise as fraught with conceptual and practical difficulties as with statesovereignty and separation-of-power concerns." 110 The D.C. Court of Appeals has pointed out as well that, in evaluating whether a taking is pretextual, there are "formidable barriers to discovering the motives and intentions of individual legislators." ${ }^{\prime 11}$ The benefits of discovery, for instance, may be minimal because normally "legislators may not be deposed or made to answer interrogatories in an attempt to disclose their individual motivations." ${ }^{112}$

Yet, at least as a descriptive matter, the difficulty of determining motivation by itself does not seem to be a sufficient reason for rejecting an intent-based test. The Supreme Court has approved similar inquiries in a number of contexts. For example, in Batson v. Kentucky, ${ }^{113}$ the Court explicitly rejected the government's argument that judicial inquiries into the purpose of prosecutors' preemptory challenges would present serious administrative difficulties. ${ }^{114}$ Similarly, in Church of Lukumi Babalu Aye, Inc. v. Hialeah, ${ }^{115}$ the Court considered the motivation of city council members and emphasized that "we may determine the city council's object from both direct and circumstantial evidence" including "the historical background of the decision under challenge, the specific series of events leading to the enactment or official policy in question, and the legislative or administrative history, including contemporaneous statements made by members of the decisionmaking body." ${ }^{116}$ Even in Whren $v$. United States ${ }^{117}$ where the Court held that the constitutional reasonableness of traffic stops does not depend on the actual motivations of the individual officers involved, Justice Scalia, writing for

\footnotetext{
${ }^{109}$ See Oswald, 35 BC Envtl Aff L Rev at 59 (cited in note 44) (concluding that "courts generally view inquiries into the motives behind eminent domain actions as off-limits").

${ }^{110}$ Goldstein, 516 F3d at 63.

${ }^{111}$ Franco, 930 A2d at 173.

${ }^{112}$ Id at 173 n 12 (citations omitted); cf. Ellickson and Been, Land Use Controls at 116 (cited in note 23) (pointing out that "courts have been quite reluctant to put too much stock in what local legislators say on the record, much less to take testimony about what the legislators might have been thinking when they cast their votes"I.

${ }^{113} 476$ US 79 (1986).

${ }^{114}$ Id at 99 .

115508 US $520(1993)$.

${ }^{116}$ Id at 540 .

${ }^{117} 517$ US 806 (1996).
} 
a unanimous Court, noted that the Court's prior cases in this area were not based only, or even principally, on the difficulty of establishing subjective intent. ${ }^{118}$ In the takings context itself, courts have developed a number of tests including "bad faith" for analyzing a condemnor's intent. ${ }^{119}$

Perhaps an even more significant concern with a test based exclusively on intent is that a condemnor may have "mixed" motives. ${ }^{120}$ The possibility of mixed motives is particularly likely when a firm threatens to relocate unless the local government utilizes eminent domain on its behalf. The problem arises because, before the relocation threat, local officials may not wish to condemn the land. Indeed, officials may view such a condemnation as a transfer that merely serves a private interest. However, after the relocation threat, officials may conclude that preventing the firm from relocating is essential and thus may decide to condemn the land for the firm. Paradoxically, therefore, officials may act in a way that is genuinely motivated by the public interest even though the purpose of the taking is solely for a private benefit. But because these threats to relocate may decrease social welfare, takings such as the condemnations at issue in Poletown or 99 Cents Only should not be immune from judicial scrutiny even though, at the time of the takings, the condemnors may have been genuinely motivated by a public purpose. ${ }^{121}$

Hence, a test for pretext based exclusively on the condemnor's intent arguably entails the problems of disutility, futility, and administrability. A test based solely on intent also would permit the use of

${ }^{118}$ Id at 814 .

${ }^{119}$ See Oswald, 35 BC Envtl Aff L Rev at 61-62 (cited in note 44) (asserting that, "although the courts in theory eschew the notion that they can inquire into the motives underlying a taking, they in practice, by acknowledging a role for evaluating the condemnor's actions for subterfuge or bad faith, open the door to at least limited inquiries about motive" (citing City of Evansville $v$ Reising, 547 NE2d 1106, 1111 (Ind Ct App 1989)I).

${ }^{120} \mathrm{Cf}$. Ellickson and Been, Land Use Controls at 115 (cited in note 23) (noting that legislation "often is motivated by a complex myriad of purposes" and discussing three possible tests for "mixed motive" cases).

${ }^{121}$ See William J. Stern, State Capitalism, New York Style, City J, 70-75 (Summer 1994) (concluding that "the practice of ad hoc deal-making to induce particular companies to stay is misguided" because "it creates an incentive for businesses to threaten to leave, even if they have no intention of doing so"l), quoted in Ellickson \& Been, Land Use Controls at 885 (cited in note 23); cf. Ralph Nader and Alan Hirsch, Making Eminent Domain Humane, 49 Vill L Rev 207, 219 n 87 (2004) (asserting that "the notion that th[e] exercise of eminent domain [in Poletown] was valuable to Detroit's economy is problematic" because "it was brought about by GM's threat to relocate, which may have been a bluff" (citation omitted)). But cf. Steve Eagle, Kelo, Directed Growth, and Municipal Industrial Policy, 17 S Ct Econ Rev 63, 104 (2009) (arguing that any test for pretext based on public benefits is likely to be futile because even in a case like 99 Cents Only local officials genuinely did not want Costco to relocate). 
eminent domain even in situations-like the cases involving threats to relocate-that clearly entail impermissible favoritism. Consequently, both the test proposed in Kelo and an intent-based test are unsatisfactory. What is needed is a framework that is able to target pretext more precisely.

\section{WHEN PRIVATE INVOLVEMENT BECOMES P R E T E X T U A L}

\section{A. Two Stages of an Assembly}

To establish a framework for identifying pretext, I first examine the possible reasons for private involvement in the condemnation process. The primary justification for such involvement is that the public might benefit if private parties are able to assist the local government in executing a development project. Because private ownership or control might increase the likelihood of a successful project, private parties may have a role in developing an assembly site. But private parties may have another role as well. Specifically, private parties may have information that the local government does not have regarding the optimal location for an assembly. Thus, private parties also may be useful in identifying the assembly site.

\section{Identifying the Site}

The first stage of an assembly is identifying the relevant site. If the local government is seeking to assemble land for one of its own projects, government officials usually will have a belief about whether an assembly is necessary and, if so, where the assembly should take place. Suppose a town is considering building a new public school. Local officials might have information regarding the school's optimal location. These officials also might have information regarding the costs of acquiring various parcels of land. If the best location for the school contained a number of homes and business, the government might have to pay a considerable sum either to purchase the land or to condemn the land and pay just compensation. Local officials might weigh the costs and benefits of this location against the costs and benefits of purchasing undeveloped land in a suitable yet suboptimal location. ${ }^{122}$

${ }^{122}$ See Garnett, 105 Mich L Rev at 110-21 (cited in note 31) (pointing out that "Takers" have an incentive to avoid properties with high subjective values); see also Mihaly, 34 Ecology L Q at 11 (cited in note 24) ("Agencies avoid acquisition of occupied residential land, whether by negotiation or condemnation, because of the expense of relocation, and, in many situations, because of the risk of political controversy."). 
By contrast, when a private party seeks to assemble land for a private project, the local government may not know whether the assembly is desirable or, if it is desirable, where the assembly should take place. Suppose that a corporation wants to assemble land for a new factory. Local officials may not know whether an assembly is necessary to build the factory. ${ }^{123}$ Moreover, even if these officials believe the assembly is necessary, the officials may not know the optimal location for the assembly. The corporation may have particular specifications regarding the parcel's size and shape, its proximity to roads and other instrumentalities of commerce, and its location in relation to the potential labor force.

A private party could share this information with the government. For example, in Poletown, General Motors had a number of specifications that it announced were necessary for its new facility. GM "told the city that it must find or assemble a parcel 450 to 500 acres in size with access to long-haul railroad lines and a freeway system with railroad marshalling yards within the plant site." ${ }^{\prime 24}$ However, whenever a private party such as GM shares information with local officials, the officials are relying on the private party's own representations and estimates. The actual value of these specifications is usually a fact that is known only by the company, not the government. In relying on this information, local officials take a risk regarding the desirability of the project unless the representations and estimates are capable of being independently verified.

To be sure, certain assemblies may have to occur in particular locations because of the nature of the project. For example, in United States v. Gettysburg Electric Railway Company, ${ }^{125}$ the federal government sought to acquire land at the Gettysburg battlefield. In that case, the location of the battlefield itself determined the site of the assembly. ${ }^{126}$ Similarly, in a town containing only one hill for a telephone tower, the local government might know that the hill is the optimal site for a company attempting to provide mobile telephone

${ }^{123}$ See Heller and Hills, 121 Harv L Rev at 1480 (cited in note 35) (pointing out "the additional difficulty of whether eminent domain sends to government and private condemnees an accurate signal of the relative value of preserving the status quo or assembling fragmented ownership patterns"); Kelly, 92 Cornell L Rev at 25 (cited in note 23) (noting that the government "may believe (albeit mistakenly) that the private assembler values the land more than the existing owners" and, consequently, "may use eminent domain to force a transfer even though the existing owners value the land more than the assembler").

${ }^{124}$ Poletown Neighborhood Council v City of Detroit, 304 NW2d 455, 467 (Mich 1981) (Ryan dissenting).

${ }^{125} 160$ US $668(1896)$.

${ }^{126}$ See id at 670 . 
and radio paging services. ${ }^{127}$ However, even this type of determination may require "extensive study and testing" to determine the optimal location. ${ }^{128}$ Of course, many other assembly projects do not require a unique site. ${ }^{129}$

The importance of this stage, identifying the optimal assembly site, is thus generally underappreciated. Disputes over eminent domain typically attract widespread attention only after a case is litigated. The view of courts, as well as the public, is thus likely to be from an ex post perspective. Indeed, while courts often focus on whether the post-condemnation use of a parcel is a "public purpose," they often do not consider the possible legal significance of the precondemnation process of identifying the site.

\section{Developing the Site}

The government also may rely on private parties to develop an assembly site. As noted above, the traditional justification for private involvement is that private developers are likely to be more effective than the government at executing certain projects. Writing for a unanimous Supreme Court, Justice Douglas emphasized in Berman $v$. Parker that "[t]he public end may be as well or better served through an agency of private enterprise than through a department of government-or so the Congress might conclude. We cannot say that public ownership is the sole method of promoting the public purposes of community redevelopment projects. ${ }^{\prime 130}$ Over fifty years later, the Kelo Court reiterated this justification for private involvement. ${ }^{131}$

Private development of a site can take a number of forms. Private involvement may be limited to assisting local officials with the construction or implementation of a public project. For example, a county that is building a new courthouse might hire a private architect, a private engineering firm, and a private construction company to complete the project. This type of project, although relying on private parties, entails the same type of public-private coordination that occurs for any government contract in which a private party may

${ }^{127}$ See, for example, Williams v Hyrum Gibbons や) Sons, 602 P2d 684 (Utah 1979).

${ }^{128}$ Id at 685.

${ }^{129}$ Cf. Heller and Hills, 121 Harv L Rev at 1492-94 (cited in note 35) (differentiating between target fragmentation and target uniqueness).

${ }^{130} 348$ US 26, 33-34 (1954).

${ }^{131}$ Kelo $v$ City of New London, 545 US 469, 486 (2005) (quoting Berman, 348 US at 33-34); cf. Mihaly, 34 Ecology L Q at 54 (cited in note 24) ("Cities recognize ... that while they can facilitate or oversee much of the redevelopment, they are not equipped to take on many aspects of the effort."). 
receive an indirect benefit. ${ }^{132}$ Typically, to the extent such involvement raises concerns about favoritism, these concerns can be mitigated by competitive bidding and other mechanisms that reduce the likelihood of corruption and private influence. ${ }^{133}$

However, instead of continuing to own the property itself, a local government may decide to transfer the land in fee simple to a private party. For example, the government might condemn several blighted parcels, assemble the properties, and transfer the land to a private developer to build condominiums or office buildings. Often this transfer is made for a nominal sum. ${ }^{134}$ Private involvement of this sort gives a developer complete control over the site. If the developer initially proposed a particular project to local officials, the developer may continue with that project after the transfer. But the developer also might decide to terminate the project and use the land for a different purpose or even to sell the land for a profit. ${ }^{135}$ Generally, this type of private involvement raises concerns about pretext because local officials retain no control over the site and private parties may obtain a significant benefit.

When a local government wants a private party to use or develop a site, but still wants to retain ownership of the land, the government may decide to lease the land to a private party. ${ }^{136}$ Such leases are

${ }^{132}$ See Mihaly, 34 Ecology L Q at 59 (cited in note 24) ("In some cases, a contract formalizes this agency relationship such that the developer simply performs its obligations for a negotiated fee.").

${ }^{133}$ See generally Lani A. Perlman, Note, Guarding the Government's Coffers: The Need For Competition Requirements to Safeguard Federal Government's Procurement, 75 Fordham L Rev 3187, 3187 (2007) ("The rules controlling the federal government's allocation of $\$ 350$ billion in contracts emphasize competition as a safeguard against collusion between government buyers and private sellers.").

${ }^{134}$ See, for example, Wendell E. Pritchett, Beyond Kelo: Thinking About Urban Development in the 21st Century, 22 Ga St U L Rev 895, 901 (2006) ("As part of the effort to prevent General Motors from building elsewhere, the city [of Detroit] spent over $\$ 200$ million to acquire and prepare the property, which it sold to the company for $\$ 8$ million." $)$.

${ }^{135}$ See Nicole Stelle Garnett, The Public-Use Question as a Takings Problem, 71 Geo Wash L Rev 936, 980 (2003) ("Obviously, if a private party received an unencumbered fee simple title to condemned land, it is free to change the use of the land at any time."); see also Kelly, 92 Cornell L Rev at 53 n 247 (cited in note 23) (pointing out that "a private party may not use the condemned land in a manner consistent with the original public purpose").

${ }^{136}$ See Garnett, 71 Geo Wash L Rev at 981 (cited in note 135)("[T] he government might retain title to the land but enter into a long term lease providing that the private party use the land for the intended public purpose."|; Mihaly, 34 Ecology L Q at 39 n 180 (cited in note 24) ("Ground leases are effective tools in redevelopment because they reduce or eliminate developers' up front land costs and enable redevelopment agencies to maintain control over a project after completion." (citing David F. Beatty et al Redevelopment in California 153 (Solano Press Books, 2d ed. 1995)I). It is also pos- 
frequently long-term leases (often, for ninety-nine years), and lease payments may be nominal as well. ${ }^{137}$ Some public-private leases contain provisions that restrict the private party's use of the land. ${ }^{138}$ If the private party deviates from the lease's terms, the deviation may constitute a material breach of the agreement. ${ }^{139}$ Some states also have enacted "clawback" statutes. If a public purpose is not being realized, these statutes allow government officials to reacquire control of a property. ${ }^{140}$ As with private ownership, however, a long-term lease raises concerns about pretext because, while the government retains an ownership interest, the private lessee usually exercises significant control over the site and may obtain a substantial benefit.

The government's reliance on private enterprise is premised on the view that the private sector is more efficient in executing certain projects. ${ }^{141}$ Yet private involvement in developing the site means that a private party is able to obtain a distinct benefit. Indeed, being selected as a private developer entails the possibility of windfall profits, especially if the developer buys or leases the land for a nominal

sible that the government could condemn only a leasehold interest and then transfer that interest to a private party. Cf. Carol L. Zeiner, Establishing a Leasehold Through Eminent Domain: A Slippery Slope Made More Treacherous by Kelo, 56 Cath U L Rev 503, 505 (2007) (suggesting that it may be "time for governmental entities to seriously consider using eminent domain to acquire less than a fee simple interest in real property when the specific need is important, of a limited-rather than an indefiniteduration, and a bargained-for exchange cannot be negotiated").

${ }^{137}$ See, for example, Kelo, 545 US at $476 \mathrm{n} 4$ (noting that the development corporation "was negotiating a 99-year ground lease with Corcoran Jennison" and that "[t]he negotiations contemplated a nominal rent of $\$ 1$ per year").

${ }^{138}$ See, for example, id at $486 \mathrm{n} 15$ ("Notably, as in the instant case, the private developers in Berman were required by contract to use the property to carry out the redevelopment plan." (citing Berman, 348 US at 30)). For a description of other ways in which the government might be able to ensure that a private party carries out a public purpose, see Garnett, 71 Geo Wash L Rev at 980-81 (cited in note 135).

${ }^{139}$ See Garnett, 71 Geo Wash L Rev at 981 (cited in note 135) (“Under these circumstances, the abandonment of the public purpose would be considered a material breach and grounds for termination of the lease.").

${ }^{140}$ See id at 978 ("A number of states have considered or adopted 'clawback' legislation penalizing the recipient of development incentives for failing to follow through on promised investment or job creation.").

${ }^{141}$ See Donald E. Sanders and Patricia Pattison, The Aftermath of Kelo, 34 Real Estate LJ 157, 167 (2005) ("If it is true that generally the free market delivers goods and services more efficiently than the government, then it is more efficient for the government to condemn the property and then transfer it to a private party for the economic development."); see also Mihaly, 34 Ecology L Q at 40 (cited in note 24) (concluding that "government has come to appreciate that developers have capabilities that government does not share" and listing a number of these capabilities including "certain project or building-specific planning expertise, development, construction, leasing and sometimes maintenance expertise" $e^{\prime \prime}$. 
sum. ${ }^{142}$ A private party thus has an incentive to lobby the government, to outmaneuver other private parties, and to threaten relocation in order to obtain the power of eminent domain. ${ }^{143}$

\section{B. Four Categories of Takings}

Because an assembly project consists of two stages, the identification stage and the development stage, private involvement is possible before the taking has occurred, after the taking has occurred, or both before and after the taking has occurred. Obviously, it is also possible for the government to exercise eminent domain without private involvement. The result is four types of takings /represented below in Figure 1) that involve varying degrees of public and private involvement.

The columns in Figure 1 indicate the source that provides the information by which a particular assembly site is identified. Thus, Column 1 ("Public Information") means that the government itself has information regarding the optimal site. Column 2 ("Private Information") means that the government has to rely on one or more private parties to provide information regarding the site. The rows in Figure 1 indicate the identity of the developer. Thus, Row 1 ("Public Development") means that the government itself continues to own the land and ultimately executes the project. Row 2 ("Private Development") means that the government sells or leases the land to one or more private parties and these parties ultimately control the property and execute the project.

Of course, the line between "public development" and "private development" is not always clear. ${ }^{144}$ For example, a local government

${ }^{142}$ See Kelly, 92 Cornell L Rev at 37-39 (cited in note 23) (describing problem of costless acquisition).

${ }^{143}$ See id at 39 (noting that private developers "will have a powerful incentive to use almost any means-including intensive lobbying, political contributions, expensive lawyers, threats to relocate, and sometimes even bribery-to obtain the takings power for their own private objectives").

${ }^{144}$ Cf. Mihaly, 34 Ecology L Q at 39 (cited in note 24) (noting that "[m]odern development mixes government and private ownership in arrangements that defeat any bright-line test"). Here, I use the term "development" rather than "ownership" to emphasize that the relevant inquiry is not whether a public or private entity formally owns the land but whether a public or private entity is the primary gatekeeper and beneficiary of the property. Cf. id at 41 (arguing that "it is much too simple to talk about 'ownership' because the proverbial bundle of sticks associated with land ownership has been deliberately broken apart and replaced with a pattern of contractual responsibilities that allocates to the respective public and private parties the specific elements of assembly, clearance, construction, maintenance, and control they are best equipped to perform for the subject development"). 


\begin{tabular}{|c|c|c|}
\hline & Public Information & Private Information \\
\hline Public Development & Category 1 & Category 2 \\
\hline Private Development & Category 3 & Category 4 \\
\hline
\end{tabular}

Figure 1. Four Categories of Takings

may use eminent domain for a revitalization project that includes both condominiums and office towers (quintessential private developments) and streets and parks (quintessential public developments). ${ }^{145}$ However, the line here is a functional, rather than formal, one, and most developments can be categorized as either public or private. For example, the project in Kelo included a "public walkway" and "state park," 146 yet most observers, including the justices in the majority, characterized the project as a private development. ${ }^{147}$ As a general matter, it seems plausible to assume that courts are usually capable of distinguishing between public and private developments. ${ }^{148}$

The two ways of acquiring information (public and private) and the two types of developers (public and private) yield four possibilities. First, an assembly may be based on public information and rely on public development (Category 1). Second, an assembly may be based on private information and rely on public development (Category 2). Third, an assembly may be based on public information and utilize a private developer (Category 3). Fourth, an assembly may be based on private information and utilize a private developer (Category 4). I examine each of these possibilities in turn. ${ }^{149}$

${ }^{145}$ See id at 38 ("Public uses are intermingled with private uses in the same development, in the same building, and even the same space within a building." (citing Todd W. Bressi, Planning the American Dream, in Peter Katz, The New Urbanism: Toward an Architecture of Community, xxx-xxxv (McGraw-Hill 1994))).

146545 US at 474.

${ }^{147}$ See id at 478 n 6 (acknowledging that "the City intends to transfer certain of the parcels to a private developer in a long-term lease-which developer, in turn, is expected to lease the office space and so forth to other private tenants").

${ }^{148}$ But cf. In re Seattle, 638 P2d 549, 556 (Wash 1981) (en banc) ("If a private use is combined with a public use in such a way that the two cannot be separated, the right of eminent domain cannot be invoked.").

${ }^{149}$ For a different categorization, see Debra Pogrund Stark, How Do You Solve a Problem Like In Kelo?, 40 J Marshall L Rev 609, 612 (2007) (analyzing three categories of takings-(i) a "'traditional taking' where the government will own the land taken," (ii) a "non-traditional taking where a private party will own the land taken," and (iii) a traditional taking or non-traditional taking "where the land taken is the property owner's home" - and proposing an increasing level of scrutiny for each category). 


\section{Public Information-Public Development}

If an assembly project is based on public information and executed by a public development, the risk that the taking is pretextual is minimal. The reason is that there is no private involvement in either identifying or developing the assembly site. Private involvement is unnecessary for identifying the site because the determination of the optimal site is based on the government's own information. Private involvement is also unnecessary for developing the site because the government, rather than a private party, is capable of executing the development.

Consequently, there is usually little concern about impermissible favoritism in traditional government takings. When a local government takes land for a public park, the government decides where the park will be located. After the assembly is complete, the government continues to own and operate the park. Individuals who enjoy exercising outdoors may frequent the park more than others. Residents who own parcels near the park may have their property values increase while others may not. But the park itself is open to all, and there is no single private party that receives a concentrated benefit.

For this category of takings, the risk of pretext is appropriately characterized as "minimal" (rather than zero) because it is possible that a public development based on public information could still be pretextual. Specifically, even if no private party is involved in identifying the site and the government continues to own and control the land, the government might use eminent domain to benefit a particular private party. ${ }^{150}$ For example, the government might condemn land in order to build a railroad line whose only destination is a private company at the end of the track. With regard to this type of project, the private beneficiary is usually readily apparent. Perhaps as a result, there is already a fairly well-developed jurisprudence for determining whether such a project is for a public or private purpose. ${ }^{151}$ Of course, simply because a project benefits one or more private parties does not imply that the taking itself is based on impermissible favoritism. ${ }^{152}$

${ }^{150}$ Id at 635 (noting that "even a literal public use-where the public has the right to use of the property taken-could serve as a pretext for a taking really designed to benefit a private party"l.

${ }^{151}$ See, for example, Union Lime Co. $v$ Chicago « Nw Ry Co., 233 US 211, 222 (1914) ("There is a clear distinction between spurs which are owned and operated by a common carrier as a part of its system and under its public obligation and merely private sidings." (collecting cases)).

${ }^{152}$ Indeed, many governmental actions involve both winners and losers in the private sector, but these actions do not involve the same type of impermissible favoritism as takings that directly benefit a particular party. See generally Abraham Bell and Gideon Parchomovsky, Givings, 111 Yale L J 547 (2001). 
Thus, "Category 1" takings, in which a public development is based on public information, involve some risk of pretext but that risk is minimal.

\section{Private Information-Public Development}

Similarly, if an assembly project is based on private information and executed by a public development, the risk of pretext is minimal. Although this category of takings does entail private involvement in the initial stage of identifying the assembly site, there is no private involvement in the subsequent stage of developing the site. The government ultimately retains ownership and control of the property. For "Category 2" takings, there is thus little risk that the assembly is pretextual.

In practice, this category of takings is relatively uncommon. Developers have virtually no incentive to share information with local officials if they do not expect to receive a benefit from the resulting assembly. If developers sometimes do have better information than officials about the location of public projects, it might be desirable to design a mechanism that encourages these developers to disclose this information.

One possible mechanism by which a local government might obtain information regarding potential assembly sites is by compensating developers through rewards or contracts. The federal government relies on similar mechanisms in other situations in which useful information is dispersed among private individuals. For example, Congress offers rewards for information regarding violations of, among other laws, the Endangered Species Act ${ }^{153}$ and the Lacey Act. ${ }^{154}$ Likewise, the Department of Interior relies on contracts with private oil companies for exploratory drilling in public oil fields. ${ }^{155}$

In the takings context, however, the administrative costs of implementing a reward system or the transaction costs of entering exploratory contracts might be relatively high. These costs would include the costs of calculating the expected social value of the private sector's information regarding public projects. Ultimately, such costs might outweigh the opportunity costs of the local government's not being able to rely on this type of information for its projects. Nevertheless, in certain situations, if the government wants to rely

${ }^{153}$ See 16 USC $\S 1540$ (d).

${ }^{154}$ See 16 USC $\S 3375(d)$.

${ }^{155}$ See, for example, Mobil Oil Exploration « Producing Se., Inc v United States, 530 US 604, 610 (2000) (discussing steps necessary for private corporation to obtain "an exploratory well drilling permit"). 
on private parties for information but is concerned about the possibility of pretext, a scheme that severs private involvement in the identification stage from private involvement in the development stage could be useful.

Overall, whenever the local government itself develops a condemned parcel, regardless of whether the government relies on public or private information, pretext is generally not a concern. As discussed below, the risk that a taking's asserted purpose is pretextual increases significantly when a project involves a private developer.

\section{Public Information-Private Development}

If an assembly project is based on public information but executed by a private developer, there is an elevated risk that the taking is pretextual. In this situation, private involvement is unnecessary for identifying the optimal assembly site because the determination of the optimal site is based on the government's own information. However, private involvement may be necessary for developing the site because a private party, rather than the government, is better able to execute the development.

Knowing that a project will require private involvement, private parties may attempt to persuade the government to designate them as the developer before a site has been identified. As George Lefcoe points out, this type of pre-condemnation private involvement is routine:

Politically connected developers confer informally with public officials about the possibility of their striking a redevelopment deal long before the formal redevelopment process begins. An experienced Florida-based land use attorney, Charles Siemon, observes that developers and local officials often reach tentative agreements before the beginning of the public review process. The negotiated deal is presented and approved at a public meeting pretty much as presented. State open meeting laws require elected officials to conduct their business in sessions that are open to the public but these laws don't bar discussions between developers and individual officials and most of them allow officials to conduct secret discussions of real estate transactions. ${ }^{156}$

${ }^{156}$ George Lefcoe, After Kelo, Curbing Opportunistic TIF-Driven Economic Development: Forgoing Ineffectual Blight Tests; Empowering Property Owners and School Districts, 83 Tul L Rev 45, 80-81 (2008) (citing Patience A. Crowder, "Ain't No Sunshine": Examining Informality and State Open Meetings Acts as the Anti-Public Norm in Inner-City Redevelopment Deal Making, 74 Tenn L Rev 623 (2007) and Charles L. Siemon, Public/Private Partnerships and Fundamental Fairness in City 
This type of pre-condemnation private involvement increases the possibility of corruption, secondary rent seeking, and relocation threats-each of which can lead to socially undesirable outcomes. ${ }^{157}$ Moreover, even when developers are not selected before the site has been identified, these problems may still exist because, after the government selects the site, developers may compete for the designation of "preferred developer."158 Thus, unlimited private involvement, either before or after the taking, increases the risk of a pretextual taking.

However, in situations in which the government does not need to rely on private information to identify the assembly site, precondemnation private involvement is generally unnecessary. As discussed above, the justification for private involvement before the taking is that a private party may have better information than the government regarding the optimal site. ${ }^{159}$ But here, because the government itself has information regarding the site, such private involvement is unnecessary. Moreover, although the government may wish to rely on a private party to execute the development, it is unnecessary for the government to select a preferred developer. ${ }^{160}$ Instead, the government can select a developer after the condemnations through a competitive process such as an auction.

Indeed, several commentators have pointed out the potential advantages of relying on mechanisms like auctions to reduce the risk of favoritism in assembly projects. For example, Perry Shapiro and Jonathan Pincus observe that "redevelopment partnerships may be legitimate ways to reduce transaction costs and share development risks, but they smack of cozy dealing between city hall and special private interests." ${ }^{161}$ Shapiro and Pincus thus propose an "open auction process" and point out that one of the attractive aspects of such

Deal Making, in Terry Jill Lassar, Introduction to City Deal Making 81 (Urban Land Institute 1990)|. For a contrasting view, see Mihaly, 34 Ecology L Q at 55 (cited in note 24) ("Most developer-selection processes reveal that, while the resulting relationship is important to both parties, it is not collusive.").

${ }^{157}$ See Part II(A).

${ }^{158}$ See id.

${ }^{159}$ See Part IV(A)(1).

${ }^{160}$ The term "preferred developer" also encompasses a "master developer" that the local government may select. See Mihaly, 34 Ecology L Q at 54 (cited in note 24) (noting that "the city may advertise for a "master developer'" who may "assist the city with planning, perform due diligence reviews concerning site issues such as contamination, and assist in estimating the cost of old infrastructure demolition and new project-related infrastructure and improvements").

${ }^{161}$ Perry Shapiro and Jonathan Pincus, Efficiency and Equity in the Assemblage of Land for Public Use: The L2H2 Auction *4 (2007), online at http://www.economics .adelaide.edu.au/workshops/workshops/2008papers/080407pincus.pdf /visited May 19, 2008). 
a process is that it "erases the suspicion of backroom cozy dealing between politicians and private interests." 162

Justice Kennedy himself might be sympathetic to such an approach. In his concurring opinion in Kelo, Kennedy emphasized that benefiting Pfizer did not appear to be the primary motivation of the project because the government had "reviewed a variety of development plans and chose a private developer from a group of applicants rather than picking out a particular transferee beforehand." 163 An auction process encourages "a group of applicants" as well. But an auction has the additional benefit of removing governmental discretion in selecting among the applicants.

This approach addresses all three of the problems created by unlimited private involvement. First, limiting pre-condemnation private involvement and post-condemnation involvement by a preferred private party reduces the possibility of corruption. Backroom deals between local officials and private parties, as well as the perception of inordinate private influence in the eminent domain process, are eliminated. Second, private parties have little incentive, either before or after the condemnation, to lobby local officials to become the preferred developer. Selecting a developer through a competitive process thus reduces secondary rent seeking. Third, private parties do not have any incentive to threaten to relocate. A party threatening relocation unless the local government condemns land on its behalf would have no way to ensure that it would be the new owner of the assembled property.

This approach also does not create the problems inherent in the existing test based on Kelo or an alternative test based on intent. Prohibiting pre-condemnation private involvement in situations in which the local government has information regarding the assembly site does not eliminate a public benefit. Because this approach only prohibits private involvement where such involvement does not entail a public benefit, disutility is not a problem. Moreover, if a court invalidated a taking based on impermissible favoritism, local officials still would be required to limit private involvement in any future attempt to condemn the land. Because it would be difficult for the government to circumvent this rule, futility is also not a problem. Finally, the local government does have information regarding certain types of takings including takings in which the reason for the

${ }^{162}$ Id at ${ }^{\star} 15$; cf. Petition for Certiorari, Goldstein v Pataki, Civil Action No 07-1247, ${ }^{*} 6$ (US filed Mar 31, 2008) (available on Westlaw at 2008 WL 899311) (pointing out that "the selection of private developers for projects that receive billions of dollars in tax breaks and direct subsidies are typically subject to competitive selection").

${ }^{163} 545$ US at 492 (Kennedy concurring). 
assembly is observable or the site is known. ${ }^{164}$ Because these types of takings can be identified in advance, administrability is also not a problem.

Admittedly, an approach that prohibits all pre-condemnation private involvement, as well as all post-condemnation involvement by a particular private developer, may be overinclusive. That is, even when a local government has information regarding the optimal assembly site, there may be certain circumstances in which private involvement is necessary, despite the risk of impermissible favoritism. For example, if a city lacks access to funding for the early stages of a project, the city may need to rely on a private developer to provide the necessary capital. ${ }^{165}$ The possibility of overinclusiveness suggests that, instead of a per se rule against pre-condemnation private involvement or post-condemnation private involvement by

${ }^{164}$ See, for example, Part V(B)(1) (discussing the observable characteristics of blight); Part V(B)(2) (discussing redevelopment districts that already exist).

${ }^{165}$ See Mihaly, 34 Ecology L Q at 54 (cited in note 24) ("Cities typically lack access to capital early in the project, [sic] cannot front high 'predevelopment' expenses (that is the costs of planners, economists, engineers, and attorneys necessary to work through the details of the project proposal)."|. Commentators also have suggested that early involvement by private parties may be useful for identifying the developer and the ultimate owners and thereby for ensuring that there is sufficient interest in the project. See Lefcoe, 17 S Cal Rev L \& Soc Just at 841 (cited in note 71) (observing that "entrepreneurial redevelopment directors began reaching out to private developers early in the planning stages" because "local governments came to appreciate the virtues of redevelopment agencies striking a deal with a developer or receiving sufficient expressions of interest and preliminary negotiations to attain confidence that the project would be completed on schedule"); Mihaly, 34 Ecology L Q at 58 (cited in note 24) (asserting that "very early in the project, even during the extensive negotiation period before a contractual relationship is cemented, the putative master developer, or the master developer and the city together, may work to identify such a potential owner who can generate revenue early in the development ${ }^{\prime \prime}$ ). However, this potential justification for pre-condemnation private involvement seems somewhat tenuous because it is possible to gauge the market's interest in purchasing an asset without engaging in a sale or a promise to sell. Cf. Sean J. Griffith, Spinning and Underpricing: Legal and Economic Analysis of the Preferential Allocation of Shares in Initial Public Offerings, 69 Brook L Rev 583, 613 (2004) (describing how underwriters "buil[d] a book of tentative orders reflecting each investor's interest in a number of shares at a particular price from which the lead underwriter will be able to gauge the level of demand for the issue and thereby arrive at a more accurate offering price that may be set within or outside of the estimated range" ${ }^{\prime \prime}$. Likewise, it would seem that a local government is capable of gauging the potential private interest in a project without committing to a particular developer. Moreover, some local governments select assembly sites without any private involvement. For example, a number of cities, including Baltimore, Maryland, have relied on Requests for Proposals (or "RFPs"), in which the condemnor takes property without having any plan for its development and then requests proposals from private developers. See Lefcoe, 83 Tul L Rev at 107-08 (cited in note 156) (discussing Mayor $\oplus$ ) City Council of Baltimore City v Valsamaki, 916 A2d 324 (Md 2007)). 
a preferred developer, a local government should be able to rely on a private developer in certain situations if it can provide a justification for such involvement. ${ }^{166}$

As a general matter, however, the risk of impermissible favoritism for this category of takings does not justify the potential benefits of private involvement. Both pre-condemnation private involvement and post-condemnation private involvement by a preferred developer often raise the likelihood of a pretextual transfer without any corresponding benefit. Thus, "Category 3" takings, in which a private development is based on public information, entail an elevated risk of pretext; yet, it may be unnecessary for society to bear this risk.

\section{Private Information-Private Development}

There is also an elevated risk that a taking is pretextual if an assembly project is based on private information and executed by a private developer. In this situation, private parties might be involved before a condemnation occurs because private information may be necessary for determining the optimal assembly site. Private parties also might be involved after the condemnation occurs either because the private party would otherwise be unwilling to provide information for determining the site or because the private party is better able to develop the site.

Prohibiting pre-condemnation private involvement and postcondemnation involvement by a preferred developer might be an effective approach for eliminating pretext in this category of takings as well. That is, if the benefits of targeting pretext outweigh the opportunity costs of foregoing private participation, it might be desirable to limit private involvement in both "Category 3" and "Category 4" takings. Indeed, scholars who advocate the use of an auction system appear to suggest that this type of system would be useful whenever a private party is involved in the development. ${ }^{167}$

However, for takings that require private information to identify the optimal site, there are two potential problems with this approach. First, a local government sometimes may need to rely on private involvement before the taking. ${ }^{168}$ Specifically, because the government does not have information regarding the optimal assembly

${ }^{166}$ See Part V(A) (proposing burden-shifting framework in which the government has the opportunity to proffer a non-pretextual reason for such private involvement); cf. Kelo, 545 US at 493 (Kennedy concurring) (suggesting the possibility that a presumption of invalidity may be "rebuttable").

${ }^{167}$ See Shapiro and Pincus, Efficiency and Equity in the Assemblage of Land for Public Use at ${ }^{\star} 12-13$ (cited in note 161).

${ }^{168}$ See Part IV(A)(1). 
site, the government may have to rely on a developer to provide this information. ${ }^{169}$ A developer also may have more of an incentive than the government to acquire this information. Eliminating pre-condemnation private involvement might therefore eliminate a potential advantage of private involvement. Second, the government sometimes may need to rely on a particular private party as the preferred developer. Without being assured of the potential benefits that accrue to the preferred developer after the taking, a developer might have little incentive to provide beneficial information before the taking.

Suppose that a private developer is aware of a promising opportunity for a new commercial development. The potential site of the development, however, is excessively fragmented among dozens of landowners. The local government may not have information regarding this opportunity or the requirements of a commercial development. If the government had to rely on its own information, the development may never be built or, if it is built, it may be constructed in a suboptimal location. By contrast, if pre-condemnation private involvement is permitted, local officials might be able to capitalize on the developer's information in order to identify the optimal location and then rely on the developer's expertise in order to execute the development. ${ }^{170}$

As discussed above, the government could sever the private involvement in the identification of the site from the private involvement in the development of the site. ${ }^{171}$ For example, the government could hire a private developer solely to provide information about the optimal location of a possible assembly site. It could then rely on a different developer to execute the project once the site has been assembled. However, as noted above, the administrative costs of implementing a reward system or the transaction costs of entering exploratory contracts might be relatively high. ${ }^{172}$ In any event, while the government could choose to rely on two private parties-one before the condemnation and one after the condemnation-such a strategy is clearly not constitutionally required.

Admittedly, by allowing pre-condemnation private involvement and post-condemnation involvement by a preferred developer in these types of takings, this approach to targeting pretext is potentially underinclusive. In certain circumstances, a local government might claim that private information is necessary for an assembly

\footnotetext{
${ }^{169}$ See id.

${ }^{170}$ See Part IV(A)(1)-(2).

${ }^{171}$ See Part IV(B)(2).

${ }^{172}$ See id.
} 


\begin{tabular}{|c|c|c|}
\hline & Public Information & Private Information \\
\hline $\begin{array}{c}\text { Public } \\
\text { Development }\end{array}$ & $\begin{array}{c}\text { (1) } \\
\text { Minimal Risk } \\
\text { (no private involvement) }\end{array}$ & $\begin{array}{l}\text { (2) } \\
\text { Minimal Risk } \\
\text { (no benefit to private parties) }\end{array}$ \\
\hline $\begin{array}{c}\text { Private } \\
\text { Development }\end{array}$ & $\begin{array}{l}\text { (3) } \\
\text { ElEVATED RISK } \\
\text { (no justification for pre- } \\
\text { condemnation involvement }\end{array}$ & $\begin{array}{l}\text { (4) } \\
\text { ELEVATED RISK } \\
\text { (possible justification for pre- } \\
\text { condemnation involvement) }\end{array}$ \\
\hline
\end{tabular}

Figure 2. Risk of Pretext in Four Categories of Takings

even though the private involvement is pretextual. Likewise, the government might assert that it is necessary to designate a particular party as the preferred developer even though the developer could have been selected through a competitive process such as an auction. Being underinclusive in situations in which local governments do not have adequate information may be necessary, however, because otherwise judges would be charged with comparing the potential costs and benefits of private involvement, a task that they have been reluctant to perform. ${ }^{173}$ Thus, although "Category 4" takings entail an elevated risk of pretext, it sometimes may be necessary for society to bear this risk.

Overall, as Figure 2 indicates, the risk of a pretextual taking varies depending on whether a taking is a public or private development. When the taking involves a public development (Category 1 or Category 2), the risk of favoritism is minimal. By contrast, when the taking entails a private development (Category 3 or Category 4), the risk of favoritism is elevated. Importantly, however, whether there is a possible justification for this elevated level of risk depends on whether private information is necessary for identifying the development site. When private information is unnecessary for identifying the site (Category 3 ), there is generally no justification for either precondemnation private involvement or post-condemnation involvement by a preferred developer. By contrast, when private information

${ }^{173}$ See notes 52 \& 71 and accompanying text. But cf. Kelly, 92 Cornell L Rev at 63 (cited in note 23) (advancing theory of public use requirement that avoids "relying on the imperfect information of either legislatures or courts"). However, even if this approach is underinclusive for "Category 4" takings, it is still likely to be superior to either relying on the timing of the identification of private parties, a test that is both underinclusive and overinclusive, see Part III/(A)(3), or the condemnor's intent, a test that is both underinclusive and entails the problems of disutility, futility, and administrability, see Part III(B). 
is necessary for identifying the site (Category 4), a possible justification exists for certain types of private involvement.

\section{A FRAMEWORK BASED ON TITLE VII}

\section{A. Takings and Title VII}

Identifying pretextual motivation is a concern in many areas of the law besides eminent domain. One area in which pretext plays a particularly prominent role is in employment discrimination cases under Title VII. In McDonnell Douglas Corporation v. Green, ${ }^{174}$ the Supreme Court created a tripartite burden-shifting framework for analyzing claims of discriminatory treatment. ${ }^{175}$ An employee may prevail on a Title VII claim if she is able to produce direct evidence of discrimination. ${ }^{176}$ If so, the McDonnell Douglas burden-shifting framework does not apply. ${ }^{177}$ However, an employee also may prevail on a Title VII claim by producing indirect evidence of discrimination and satisfying the burden-shifting test. ${ }^{178}$ Under this test, even if an employer is able to articulate a legitimate, nondiscriminatory reason for its employment action, the employee can still prove disparate treatment by offering evidence that the employer's explanation is pretextual. ${ }^{179}$

Since McDonnell Douglas, this burden-shifting framework has been extended from Title VII cases to several other contexts involving a concern about pretext. For example, in Batson $v$. Kentucky, ${ }^{180}$ the Supreme Court explicitly adopted the Title VII framework for analyzing challenges to preemptory strikes. ${ }^{181}$ Likewise, several fed-

174411 US 792 (1973).

175 See id at 802-05.

${ }^{176}$ See Swierkiewicz v Sorema N. A., 534 US 506, 511 (2002) ("II]f a plaintiff is able to produce direct evidence of discrimination, he may prevail without proving all the elements of a prima facie case.").

${ }^{177}$ See Trans World Airlines, Inc v Thurston, 469 US 111, 121 (1985) (noting that "the McDonnell Douglas test is inapplicable where the plaintiff presents direct evidence of discrimination").

${ }^{178}$ See McDonnell Douglas, 411 US at 802 (setting forth requirements of a prima facie case); see also Desert Palace, Inc $v$ Costa, 539 US 90 (2003) (holding that direct evidence of discrimination is not required to prove employment discrimination in mixed-motive cases under Title VII).

${ }^{179}$ See McDonnell Douglas, 411 US at 802-05.

180476 US 79 (1986).

${ }^{181}$ See Robin Charlow, Tolerating Deception and Discrimination After Batson, 50 Stan L Rev 9, 23-24 (1997) (pointing out that "Batson's procedural framework for assessing whether a peremptory strike violates the equal protection principle, and 
eral courts of appeals have adopted the Title VII framework in analyzing discrimination claims under the Americans with Disabilities Act. ${ }^{182}$ A number of circuits also have relied on the test in evaluating gender discrimination claims under Title IX. ${ }^{183}$

In this section, I suggest that Title VII's burden-shifting framework can and should be adopted in the takings context to provide a practicable mechanism for identifying when private involvement becomes pretextual. For takings claims arising under state law, the proposed framework could be enacted by state legislatures or adopted by state courts. For takings claims arising under federal law, the framework could be implemented by Congress or adopted by federal courts. ${ }^{184}$ Whether under state or federal law, the burden-shifting test would involve three steps: the condemnee's prima facie case, the condemnor's burden to rebut the prima facie case by offering a legitimate justification for private involvement, and the condemnee's opportunity to prove that the condemnor's justification is pretextual.

\section{Condemnee's Prima Facie Case}

Under the McDonnell Douglas framework, a plaintiff must first establish a prima facie case of discrimination. ${ }^{185}$ In the takings con-

indeed the very term 'pretext,' are borrowed from Supreme Court opinions in employment discrimination cases arising under that civil rights law" (citing Batson, 476 US

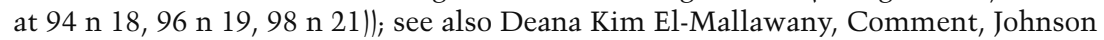
v California and the Initial Assessment of Batson Claims, 74 Fordham L Rev 3333, $3346 \mathrm{n} 83$ (2006) ("Since adopting the three-part framework in Batson, the Court has regularly relied on Title VII cases to shed light on the burden-shifting process." (collecting cases)|.

${ }^{182}$ See Raytheon Co v Hernandez, 540 US 44, 49 n 3 (2003) (noting that "Courts of Appeals have consistently utilized this burden-shifting approach when reviewing motions for summary judgment in disparate-treatment cases" (citing Pugh v Attica, 259 F3d 619, 626 (7th Cir 2001) (applying burden-shifting approach to a disparatetreatment claim under the American with Disabilities Act)|l.

${ }^{183}$ See, for example, Brine v Univ of Iowa, 90 F3d 271, 276 (8th Cir 1996) (concluding that the Title VII standards should apply to claims arising under Title IX); Lipsett v Univ of Puerto Rico, 864 F2d 881, 897 (1st Cir 1988) (same); see also Catherine Pieronek, Title IX Beyond Thirty: A Review of Recent Developments, 30 JC \& UL 75, 117 (2003) ("Both Title VII and Title IX employ the burden-shifting framework articulated in McDonnell Douglas Corp v Green.").

${ }^{184}$ Most federal takings claims will arise in state court (as in Kelo) because of the procedural requirements that apply to takings claims after Williamson County Regional Planning Commission v Hamilton Bank of Johnson City, 473 US 172 (1985), and San Remo Hotel $v$ City and County of San Francisco, 545 US 323 (2005). See William A. Fletcher, Kelo, Lingle, and San Remo Hotel: Takings Law Now Belongs to the States, 46 Santa Clara L Rev 767, 777-78 (2006).

${ }^{185}$ See McDonnell Douglas, 411 US at 802. 
text, the primary concern is favoritism. Thus, in the first step, a condemnee would be required to demonstrate that a taking involves the possibility of favoritism, a showing that could be made in one of two ways.

First, the condemnee could provide direct evidence of favoritism. Direct evidence of favoritism might include a "smoking gun" such as an email exchange between a local official and a private developer that indicates that the actual purpose of the taking is to benefit the developer. As in the Title VII context, in which it is often difficult for plaintiffs to provide direct evidence of discrimination, ${ }^{186}$ it is rather unlikely that a condemnee would be able to produce direct evidence of favoritism. ${ }^{187}$ However, if the condemnee is able to produce such evidence, the condemnee would be entitled to prevail without proving the other elements of a prima facie case. ${ }^{188}$

Second, the condemnee could establish a prima facie case of favoritism through indirect evidence. To establish a prima facie case, the condemnee would be required to prove two elements. First, the condemnee would be required to demonstrate that the project involves a private party. The involvement of a private party is a logical element of the prima facie case because the risk of pretext is minimal without private involvement. ${ }^{189}$ Second, the condemnee would be required to show that, as a result of the assembly, the private party might obtain a distinct benefit. A possible benefit to the private party is also a logical element of the prima facie case because favoritism is only possible in a project in which a private party expects to obtain an advantage. ${ }^{190}$

Clearly, a condemnee would not be able to establish a prima facie case for every taking. For example, if a local government attempts to take land for a public school, a condemnee's claim that the taking is pretextual would fail at step one. Here, no private party is involved. Likewise, if a development corporation, which is typically a private

${ }^{186}$ See Hoffman v Caterpillar, Inc, 256 F3d 568, 576 (7th Cir 2001) ("Direct evidence cases, like this one, are very rare in the employment discrimination context because employers are generally very careful to avoid statements that suggest discriminatory intent-whether their true intentions are discriminatory or not." |; see also Price Waterhouse v Hopkins, 490 US 228, 271 (1989) (O'Connor concurring) ("[T]he entire purpose of the McDonnell Douglas prima facie case is to compensate for the fact that direct evidence of intentional discrimination is hard to come by.").

${ }^{187}$ Cf. Franco v Nat'l Capital Revitalization Corp, 930 A2d 160, 169 (DC 2007) (pointing out that "government will rarely acknowledge that it is acting for a forbidden reason").

${ }^{188}$ See notes 176-77 and accompanying text.

${ }^{189}$ See Part IV (B)(1).

${ }^{190}$ See Part IV (B)(2)-(4). 
nonprofit entity, ${ }^{191}$ attempts to condemn land for a public development, a condemnee's claim that the taking is pretextual would fail at step one as well. Here, although the project does involve a private party (the development corporation), the development corporation is a nonprofit entity and does not expect to obtain a distinct benefit from the taking. ${ }^{192}$

By contrast, if a local government or development corporation planned to condemn several parcels and then transfer these parcels to a private developer, a condemnee might be able to establish a prima facie case. Such a project involves a private party (the developer), and the developer anticipates obtaining a distinct benefit (the expected profits from the development). As in the Title VII context, the burden on the condemnee to establish a prima facie case would be relatively light. ${ }^{193}$ Indeed, private parties in both "Category 3 " and "Category 4" takings are normally willing to assist the government only because they anticipate obtaining some type of benefit. Thus, private involvement in the development of a site would usually result in a condemnee's being able to satisfy step one.

\section{Condemnor's Burden}

Under McDonnell Douglas, if an employee is able to satisfy step one, the burden shifts to the employer. Step two requires the employer to articulate a legitimate, nondiscriminatory reason for its employment action. ${ }^{194}$ By analogy, in the takings context, if the condemnee is able to satisfy step one, the burden would shift to the condemnor. Step two would require the condemnor to articulate a legitimate justification for private involvement in the taking.

Importantly, if the condemnor simply asserted one or more of the traditional public purposes, such as eliminating urban blight, preserving open space, generating new jobs, retaining existing jobs, or bolstering the tax base, that assertion by itself would not be sufficient to satisfy step two. While many courts have held that these justifications satisfy the public use requirement, such justifications do not indicate whether, and to what extent, private involvement is

\footnotetext{
${ }^{191}$ See, for example, Kelo v City of New London, 545 US 469, 473 (2005) (noting that "respondent New London Development Corporation" is "a private nonprofit entity"). ${ }^{192} \mathrm{Id}$.

${ }^{193}$ Cf. St Mary's Honor Center v Hicks, 509 US 502, 506 (1993) (characterizing the requirements for establishing a prima facie case under McDonnell Douglas as "minimal"); Zamora v Elite Logistics, Inc, 478 F3d 1160, 1171 (10th Cir 2007) (noting that the burden of establishing a prima facie case of discrimination under Title VII is "so light that only the most baseless of claims fails to satisfy it").

${ }^{194}$ See McDonnell Douglas, 411 US at 802-03.
} 
necessary for an assembly. For example, while an assembly based on blight may involve a private party that executes the development, the existence of blight by itself does not determine whether precondemnation private involvement or post-condemnation involvement by a preferred developer is warranted. ${ }^{195}$ Thus, in attempting to justify private involvement, the condemnor could not rely solely on one or more of the general justifications for eminent domain.

Rather, the condemnor would be required to provide a specific justification for why a particular type of private involvement is necessary for the project at issue. For example, if a local government is able to show that a particular private party is necessary because of the information that party possesses and that pre-condemnation private involvement is not possible without designating the party as the post-condemnation developer, then the government might be able to satisfy its burden. Similarly, if the government is able to show that post-condemnation private involvement by a specific developer is necessary because that developer is the only firm technically capable of developing a particular site, then the condemnor also might be able to satisfy its burden. In each case, however, the government would be required to provide a specific justification for why precondemnation private involvement or post-condemnation involvement by a particular developer is necessary for that project.

\section{Proving Pretext}

Under McDonnell Douglas, if the employer meets its burden in step two, the presumption of intentional discrimination disappears. However, in step three, the employee can still prove disparate treatment by demonstrating that the employer's explanation is pretextual. ${ }^{196}$ Similarly, in the takings context, if the condemnor is able to meet its burden in step two, then the burden would shift back to the condemnee. To prevail in step three, the condemnee would be required to demonstrate that the condemnor's proffered justification for private involvement is pretextual.

The primary way in which a condemnee could demonstrate pretext at step three is to show that pre-condemnation private involvement or post-condemnation involvement by a preferred private party is actually unnecessary. For example, the condemnee could establish that a taking was pretextual by showing that the private developer involved in the project could have been, but was not, selected after the condemnation through a competitive process such as an auction.

${ }^{195}$ See Part V (B)(1).

${ }^{196}$ See McDonnell Douglas, 411 US at 804-05. 
As discussed above, when a local government is capable of selecting a private party through a competitive process but decides not to do so the taking should be considered pretextual. ${ }^{197}$ By not relying on such a process, the government creates an elevated risk of impermissible favoritism. This elevated risk of favoritism is also not offset by the possibility of any countervailing public benefits. If the condemnee is able to establish that the condemnor's asserted purpose for private involvement cannot be justified, then the court should rule that the condemnee has satisfied step three and declare the taking to be pretextual.

On the other hand, if a local government does rely on a competitive process, then there is little or no risk of impermissible favoritism. ${ }^{198}$ In these circumstances, a private party is not involved in the project before the condemnation, and a particular private party is not selected by the government after the condemnation. Selection of a private developer through a neutral process ensures that the condemnation does not entail impermissible favoritism. The court should rule, therefore, that the private involvement is not pretextual.

\section{B. Applications}

\section{Blighted Areas}

When a local government condemns property because it is blighted, the government typically elects to redevelop the land rather than leaving it vacant. The government often engages in this type of redevelopment by transferring or leasing the land to a private developer. ${ }^{199}$ Yet, this type of private involvement can increase the risk that a taking is pretextual. ${ }^{200}$ Indeed, many courts have been hesitant to approve blight designations in cases in which the circumstances indicate that the taking may be pretextual. ${ }^{201}$ Nevertheless, the government may have an interest in relying on a private party to develop a site after the blight has been eliminated. ${ }^{202}$

${ }^{197}$ See Part IV(B)(3).

${ }^{198}$ See id.

${ }^{199}$ See Part IV(A)(2); see also Lefcoe, 83 Tul L Rev at 67 (cited in note 156) ("Developers often initiate economic development projects, and reach tentative understandings with redevelopment agencies before the agency hires the consulting firm that will find whatever blight the law requires."); Ellickson and Been, Land Use Controls at 861 (cited in note 23) ("In most renewal projects, ... the agency itself did not act as a developer. Instead, it typically would sell a cleared parcel to a private firm, subject to covenants designed to achieve plan objectives.").

${ }^{200}$ See Part IV (B)(3)-(4).

${ }^{201}$ See, for example, Franco, 930 A2d at 169.

${ }^{202}$ Most courts have concluded that eliminating blight is a "public purpose" and that previously blighted land can be transferred to one or more private parties. The 
In addition to deciding whether or not to rely on a private party to develop a previously blighted area, the government also must make the initial determination of whether an area is actually blighted. Factors for determining blight have varied across time ${ }^{203}$ and continue to vary across jurisdictions. ${ }^{204}$ Yet a common feature of blight is that it is usually observable. For example, in Berman v. Parker, the National Capital Planning Commission (NCPC) declared an area in Southwest Washington, D.C. blighted because, among other things, " $57.8 \%$ of the dwellings had outside toilets, $60.3 \%$ had no baths, $29.3 \%$ lacked electricity, $82.2 \%$ had no wash basins or laundry tubs, [and] $83.8 \%$ lacked central heating. " 205 Modern characteristics of blight include everything from lack of a "two-car attached garage" 206 to a yard that failed to meet "minimum size requirements," 207 but these types of characteristics are observable as well.

Because blight factors are usually observable, the local government itself is generally able to identify blighted areas without rely-

Michigan Supreme Court, in overruling Poletown, carved out an exception for blight condemnations. See County of Wayne v Hathcock, 684 NW2d 765, 782-83 (Mich 2004). Likewise, the dissenters in Kelo distinguished blight condemnations from economic development takings on the basis that targeting blight involves eliminating an affirmative harm. See Kelo, 545 US at 500 (O'Connor dissenting). For an argument that eminent domain is an undesirable mechanism for revitalizing blighted neighborhoods, see Steven J. Eagle, Does Blight Really Justify Condemnation?, 39 Urb Law 833,833 (2007) (contending that, although "blackletter law provides that the presence of blight justifies condemnation, ... 'blight condemnation' is dubious at best, both in theory and practice"); cf. Kelo, 545 US at 520 (Thomas dissenting) (asserting that "if the slums at issue [in Berman] were truly 'blighted,' then state nuisance law, not the power of eminent domain, would provide the appropriate remedy." (citations omitted)).

${ }^{203}$ See Somin, 15 S Ct Econ Rev at 265-66 (cited in note 4) ("Early blight cases in the 1940s and 1950s upheld condemnations in areas that closely fit the layperson's intuitive notion of 'blight': dilapidated, dangerous, disease-ridden neighborhoods.... In the years since those early cases, many states have expanded the concept of blight to encompass almost any area where economic development could potentially be increased."). After Kelo, several states have tightened their statutory definitions of blight. See Eagle, 39 Urb Law at 835 (cited in note 202) (discussing "recent statutory limitations on blight").

${ }^{204}$ For an overview of post-Kelo definitions of blight, see generally Somin, 93 Minn L Rev at 2120-31 (cited in note 23); for an earlier survey, see Hudson Hayes Luce, The Meaning of Blight: A Survey of Statutory and Case Law, 35 Real Property, Probate \& Trust J 389 (2000).

${ }^{205} 348$ US 26, 30 (1954).

${ }^{206}$ Christopher Serkin, Local Property Law: Adjusting the Scale of Property Protection, 107 Colum L Rev 883, 910 n 118 (2007) (citing 60 Minutes: Eminent Domain (CBS television broadcast Sept 28, 2003)).

${ }^{207}$ Morriss, $17 \mathrm{~S} \mathrm{Ct} \mathrm{Econ} \mathrm{Rev} \mathrm{at} 237$ (cited in note 8) (quoting Patricia E. Salkin and Lora A. Lucero, Community Redevelopment, Public Use, and Eminent Domain, 37 Urb Law 201, 219 (2005) (citing 60 Minutes: Eminent Domain (CBS television broadcast Sept 28, 2003)1. 
ing on private developers. Consequently, pre-condemnation private involvement is typically unnecessary. Moreover, although the local government may wish to rely on a private party to develop a previously blighted area, the government normally does not need to rely on a preferred private developer. Instead, the government is capable of using an auction or other mechanism to select a developer without creating a risk of impermissible favoritism. ${ }^{208}$

As a result, an assembly project involving blight condemnations, such as the takings at issue in Berman, ${ }^{209}$ could be analyzed under the burden-shifting framework discussed above. ${ }^{210}$ Indeed, the condemnee in Berman, an owner of a non-blighted department store in Washington, D.C., may have been able to establish a prima facie case of favoritism. The District of Columbia Redevelopment Land Agency (the "Agency") intended to transfer the assembly site to private developers, ${ }^{211}$ satisfying the first element of a prima facie case, ${ }^{212}$ and those developers would have expected to obtain a benefit from redeveloping the site $^{213}$ satisfying the second element of a prima facie case. ${ }^{214}$

If Berman did satisfy step one, the burden would have shifted to the Agency as condemnor. The Agency would have been required to provide a legitimate reason for the particular type of private involvement that was expected to occur. A simple assertion by the Agency that many of the properties within the development area were "blighted" would not have been sufficient. If the Agency had argued that it was necessary to rely on private developers before the taking, the Agency may have had a difficult time justifying its position. The existence of blight in Southwest Washington, D.C. was so apparent that the Agency did not need to rely on private information to identify the site. ${ }^{215}$ Moreover, because "[n]inety-nine percent of the buildings in the Southwest were torn down," 216 it does not appear

${ }^{208}$ See Shapiro and Pincus, Efficiency and Equity in the Assemblage of Land for Public Use at ${ }^{\star} 15$ (cited in note 161 ).

${ }^{209}$ Berman, 348 US at 26.

${ }^{210}$ See Part V(A). For an overview of redevelopment efforts in Washington, DC in the 1950s, see generally Howard Gillette, Jr., Between Justice and Beauty: Race, Planning, and the Failure of Urban Policy in Washington, DC 155-65 (Johns Hopkins U 1995).

${ }^{211}$ See Berman, 348 US at 31 (noting Berman's objection that his property "will be put into the project under the management of a private, not a public, agency and redeveloped for private, not public, use"); id at 33 (noting that "one of the means chosen is the use of private enterprise for redevelopment of the area").

${ }^{212}$ See text accompanying note 189.

${ }^{213}$ See Gillette, Jr., Between Justice and Beauty at 155 (cited in note 210) (describing the "enthusiasm of local developers for slum clearance").

${ }^{214}$ See text accompanying note 190.

${ }^{215}$ See text accompanying note 205.

${ }^{216}$ Gillette, Jr., Between Justice and Beauty at 163 (cited in note 210). 
that the parcels at issue required the specific expertise of particular developers after the taking. ${ }^{217}$ In order to carry its burden at step two, the Agency most likely would have had to establish that any private involvement would occur only after the condemnation of the site and that such private involvement would not entail the use of preferred developers.

Assuming the Agency was able to provide a legitimate reason for post-condemnation private involvement, the burden would have then shifted back to Berman. Berman would have had the opportunity to offer evidence that the expected involvement of private developers was pretextual. For example, Berman may have been able to argue that the Agency was able, but failed, to select private developers through a competitive process. Based on the district court's recitation of the facts, it is not clear whether the Agency's bidding process for the site was, in fact, entirely competitive. ${ }^{218}$ If the Agency failed to rely on a competitive process, the selection of developers might have entailed an elevated risk of pretext and Berman may have prevailed at step three. ${ }^{219}$

It is also possible, as in Berman, that the government might attempt to designate an entire area as "blighted" even though the area includes both blighted and non-blighted parcels ${ }^{220}$ In analyzing these cases, courts should identify whether or not the blighted and nonblighted properties are intermingled. Where the blighted and nonblighted properties are intermingled, as in Berman, ${ }^{221}$ the analysis of pretext should proceed as if the entire area was blighted. Accordingly, assuming that the jurisdiction permits condemnations on the basis

${ }^{217} \mathrm{Cf}$. id at 156 (discussing a number of plans and noting that "the most influential plan proposed for the Southwest was one envisioning wholesale redevelopment").

${ }^{218}$ See Schneider v District of Columbia, 117 F Supp 705, 708 (DDC 1953) (threejudge court), aff'd sub nom, Berman v Parker, 348 US 26 (1954) (noting that the "Agency advertised for proposals to negotiate for the purchase or lease of land in the project area" and "[a]fter due consideration the Agency accepted the proposals of five bidders who owned property in the area ... , each to repurchase its present property, and of the Bush Construction Company for the remainder of the area"l.

${ }^{219}$ The urban renewal project at issue in Berman actually evolved from a plan with "the more modest goal of improving the area for its existing residents," Gillette, Jr., Between Justice and Beauty at $272 \mathrm{n} 55$ (cited in note 210) (citing report of the community meeting on Southwest in the Washington Star, Nov. 21, 1952), to an initiative that "encouraged planners to shift to 'the maximum-optimum' development proposal offered by the New York real estate developer William Zeckendorf," id (quoting correspondence from John Searles to James Goode, July 15, 1983).

${ }^{220}$ See, for example, Berman, 348 US at 34; Franco, 930 A2d at 171; see also Lefcoe, 17 S Cal Rev L \& Soc Just at 825 (cited in note 71) (explaining that "[c]ourts usually approve takings of unblighted properties located within blighted areas if local officials believe the taking to be necessary for achieving the redevelopment plan" and citing Berman as an example).

${ }^{221} 348$ US at 34. 
of blight, private involvement in the taking should be analyzed under the burden-shifting framework described above. By contrast, where the blighted and non-blighted properties are not intermingled, as in Goldstein v. Pataki, 222 the court should invoke a "severance" doctrine and analyze both areas separately. ${ }^{223}$ Accordingly, in the absence of any controlling statutory law, ${ }^{224}$ condemnation of the blighted portion should be analyzed as a taking in a blighted area, and condemnation of the non-blighted portion should be analyzed as a taking in a redevelopment district ${ }^{225}$ or a new assembly. ${ }^{226}$

\section{Redevelopment Districts}

The definition of a redevelopment district, like the definition of a blighted area, varies by jurisdiction. Certain states include blighted parcels in redevelopment districts, while other states explicitly distinguish between blight and redevelopment. ${ }^{227}$ Redevelopment districts that do not include blight often target parcels that are "deteriorating." Deterioration, like blight, is a determination based on the physical characteristics of existing structures, so it is typically observable as well.

Because deterioration is typically observable, the government usually does not need to rely on a private party for information regarding the assembly site. For takings in redevelopment districts, pre-condemnation private involvement is thus generally unnecessary. Although a local government may wish to utilize a private party

${ }^{222} 516$ F3d 50, 53 (2d Cir 2008) (noting that, although approximately half of the project site lies within "a heavily blighted area," the site also includes "an adjacent parcel of land with less blight ... that is currently held by private parties").

${ }^{223}$ Cf. Gallenthin Realty Dev, Inc v Borough of Paulsboro, 924 A2d 447, 464 (NJ) 2007) (holding that, "although non-blighted parcels may be included in a redevelopment plan if necessary for rehabilitation of a larger blighted area, the record contains no evidence suggesting that the Gallenthin property is integral to the larger BP/Dow Redevelopment Area" (internal citation omitted)).

${ }^{224}$ Since Kelo, a few states have explicitly prohibited the government from including non-blighted properties in blighted areas. See Dana, $32 \mathrm{Vt}$ L Rev at $168 \mathrm{n} 72$ (cited in note 28) (noting statutes in Minnesota and Wisconsin); Lefcoe, $83 \mathrm{Tul} \mathrm{L} \mathrm{Rev} \mathrm{at}$ 51-52 (cited in note 156) (describing amended North Carolina statute). Other states have significantly restricted the taking of non-blighted properties in blighted areas. See, for example, Lefcoe, 17 S Cal Rev L \& Soc Just at 826-27 \& n 132 (cited in note 71) (discussing West Virginia statute).

${ }^{225}$ See Part $\mathrm{V}(\mathrm{B})(2)$.

${ }^{226}$ See Part $\mathrm{V}(\mathrm{B})(3)$.

${ }^{227}$ See, for example, City of Minneapolis V Wurtele, 291 NW2d 386, 388 (Minn 1980) ("The Development District Law, Minn. Stat. ch. 472A (1978), was designed to allow municipalities to designate as 'development districts' areas which, while not yet 'blighted,' show a trend toward decreasing economic utility and tax base."). 
for the post-condemnation development, the government does not need to select a preferred developer. Instead, the government could use an auction or other competitive mechanism to select a developer without creating a risk of impermissible favoritism. ${ }^{228}$

Moreover, in some cases, redevelopment districts already exist. For these districts, like districts in which deterioration is observable, pre-condemnation private involvement is unnecessary. The local government already knows the boundaries of the assembly site. Similarly, if a condemnor attempts to expand an existing redevelopment district to justify additional development outside of the district's boundaries, ${ }^{229}$ private involvement should also be limited. In these cases, the primary development site has already been identified so private developers normally will not have any advantage over the local government in identifying areas adjacent to the site that are suitable for redevelopment.

\section{New Assemblies}

New assemblies differ from condemnations in both blighted areas and redevelopment districts. For new assemblies, a private developer, rather than the local government, may have information regarding the desirability of a particular site. Before the condemnation, the government may therefore need to rely on a developer for a non-pretextual purpose. After the condemnation, the government also may need to rely on a particular developer because a developer might be unwilling to provide information about the optimal site if the developer does not expect to obtain some benefit from the assembly.

As an empirical matter, local governments may have information regarding the optimal site for certain new assemblies. After all, local officials have access to land records, and these records might indicate that an area is excessively fragmented. The burden-shifting framework is thus potentially underinclusive: it allows pre-condemnation private involvement for new assemblies even though, for at least some of these projects, the government's information might have been sufficient to identify the site. Such a framework also means that, all other things being equal, condemnations involving nonblighted land would be subject to less scrutiny than condemnations involving blighted land. As a result, a developer may have an incentive to propose a new assembly rather than developing a previously

${ }^{228}$ See notes 161-62 and accompanying text.

${ }^{229}$ See Lefcoe, 83 Tul L Rev at 64-65 (cited in note 156) (pointing out that "[m]any redevelopment agencies have included already commenced projects into a newly formed redevelopment project area" and thus "stretch[ed] the boundaries of an existing project area to encompass a purely private development about to be built" ${ }^{\prime \prime}$. 
blighted parcel even though, from a social perspective, development of the blighted parcel might be more desirable.

However, the framework also has two implications that may mitigate this potential concern regarding underinclusiveness. First, by subjecting condemnations in which private information is unnecessary to a more stringent test, the framework creates an incentive for local governments not to label parcels as "blighted" areas or "redevelopment" zones. These labels can stifle economic development and cause property values to depreciate. ${ }^{230}$ Second, the framework may be appropriate in light of the political economy of takings. The framework is more permissive for those situations (viz., new assemblies) in which there is likely to be greater political resistance and more restrictions on the use of eminent domain and less permissive for those situations (viz., blighted areas and redevelopment districts) in which there is likely to be less political resistance and fewer restrictions on the use of eminent domain. ${ }^{231}$ Indeed, after Kelo, many states have eliminated or restricted the use of eminent domain for new projects in which the sole justification is "economic development." ${ }^{\prime 232}$ The major post-Kelo issue has been to what extent local officials may rely on expansive definitions of blight to condemn land for private parties. ${ }^{233}$ This framework eliminates the possibility of pretext in precisely those situations in which impermissible favoritism is most likely to still be a significant concern.

\section{Positive Externalities}

Assembly projects also entail the possibility of positive externalities. The potential beneficiaries in assemblies with externalities are

${ }^{230} \mathrm{Cf}$. Lefcoe, $17 \mathrm{~S} \mathrm{Cal} \mathrm{Rev} \mathrm{L} \mathrm{\&} \mathrm{Soc} \mathrm{Just} \mathrm{at} 821$ (cited in note 71) (noting that findings of "blight" are "occasionally challenged by homeowners fearing that an official designation of blight will hurt property values" (internal quotation marks and citation omitted)).

${ }^{231}$ Cf. David A. Dana, The Law and Expressive Meaning of Condemning the Poor After Kelo, $101 \mathrm{Nw}$ U L Rev 365, 378-82 (2007) (discussing the "legal privileging of blight condemnation (as compared to economic development condemnations)" and concluding that "[t]he effects of the legal differentiation ... will not be merely expressive but also, straightforwardly, economic: this differentiation may change the economics of land development so as to produce more condemnations in poorer areas by making land assembly more expensive in middle-class neighborhoods relative to poor neighborhoods").

${ }^{232}$ See Garnett, 105 Mich L Rev at 137 (cited in note 31) ("Almost all post-Kelo reform proposals would extend property rule protection against eminent domain, either by prohibiting 'economic development' takings outright or by limiting the funds available for such takings.").

${ }^{233}$ See Somin, 93 Minn L Rev at 2120-31 (cited in note 23) (discussing broad blight exemptions). 
not only the private parties who develop the assembly site but also the private parties who might obtain spillovers from the project. The issue of externalities must therefore be examined from the perspective of both private developers who are considering whether to develop parcels and private beneficiaries who may profit from an assembly's external effects.

If an assembly project entails a positive externality, a private developer may be unwilling to execute the project even though it would be socially desirable. ${ }^{234}$ To solve this problem, the government can provide a subsidy to the party that is ultimately selected as the developer. ${ }^{235} \mathrm{~A}$ subsidy is even compatible with selecting a developer through an auction. As long as the subsidy is set correctly and the parties who are bidding to become the developer know that the eventual developer will receive the subsidy, then each developer's private incentive to bid for the project will be aligned with the optimal social incentive. Consequently, the possible existence of a positive externality is not an adequate justification for either pre-condemnation private involvement or post-condemnation private involvement by a preferred developer.

An additional problem arises, however, in considering the potential external effects of an assembly project on other private parties. Because of these effects, private parties who are not directly involved in the project-either in providing information about the assembly site or in developing the site-may still have an incentive to lobby for a particular project or to threaten to relocate if a particular project does not occur. As noted above, this type of strategic behavior is possible in situations involving public developments that rely on public information. ${ }^{236}$ Yet, it is also possible in situations involving private developments such as the assembly project at issue in Kelo.

Indeed, in Kelo, it is noteworthy that there were two private entities that expected to benefit from the redevelopment project: Corcoran Jennison (the potential developer of the assembly site) and Pfizer Corporation (the recent purchaser of a nearby parcel). ${ }^{237}$ The Supreme Court noted that the New London Development Corporation was "negotiating a 99-year ground lease with Corcoran Jennison" and that these negotiations were initiated "[w]hile this litigation was pending before the Superior Court. ${ }^{\prime 238}$ Corcoran Jennison's involvement thus occurred relatively late in the assembly process.

\footnotetext{
${ }^{234}$ See Kelly, 92 Cornell L Rev at 42 (cited in note 23).

${ }^{235}$ See id at $44-45$.

${ }^{236}$ See notes 150-51 and accompanying text.

${ }^{237}$ See note 96.

${ }^{238}$ Kelo, 545 US at $476 \mathrm{n} 4$.
} 
By contrast, Pfizer's interest in the project was apparent from the very beginning of the process. ${ }^{239}$ While Pfizer's arrival in New London had the potential to assist in the city's revitalization, Pfizer was also in a position to obtain a significant benefit from the spillover effects of the assembly project. ${ }^{240}$

Ultimately, although Justice Thomas characterized the project as being "suspiciously agreeable to the Pfizer Corporation," Court deferred to the trial court's determination that there was "no evidence of an illegitimate purpose in this case." ${ }^{242}$ The Court therefore concluded that "the City's development plan was not adopted 'to benefit a particular class of identifiable individuals. '"243 However, additional evidence that was revealed after the Court's decision indicates the pervasiveness of Pfizer's pre-condemnation involvement with various state and local officials. ${ }^{244}$ This evidence suggests that pretext is a distinct possibility even when a private developer is not the private party being favored. Thus, under the burden-shifting framework, a condemnee could satisfy the first element of the prima facie case by establishing the involvement of a private beneficiary other than the private developer.

\section{Changed Circumstances}

Another situation in which pretext may arise is if local officials condemn land for a traditional public use (e.g., to build a park) and then announce that, rather than using the land for its original purpose, the parcel will be transferred to a developer for a private project. ${ }^{245}$ In

\footnotetext{
${ }^{239}$ Id at 473 (describing Pfizer's 1998 announcement to build a "\$300 million research facility on a site immediately adjacent to Fort Trumbull").

${ }^{240}$ See Gideon Kanner, The Public Use Clause: Constitutional Mandate or "Hortatory Fluff"?, 33 Pepp L Rev 335, 342 (2006) ("This was a case, not of an independently conceived and executed municipal redevelopment effort that incidentally benefited Pfizer when it came upon the scene, but of a jointly planned project that would avowedly inure to Pfizer's substantial benefit.").

${ }^{241}$ Kelo, 545 US at 506 (Thomas dissenting).

${ }^{242}$ Id at 478.

${ }^{243}$ Id (quoting Hawaii Housing Authority v. Midkiff, 467 US 229, 245 (1984)).

${ }^{244}$ See Somin, 15 S Ct Econ Rev at 237 (cited in note 4) ("Despite longstanding denials by both Pfizer executives and New London officials, documents obtained by The Day through state Freedom of Information Act requests show that the NLDC condemnations were undertaken in large part as a result of extensive Pfizer lobbying of state and local officials. Pfizer representatives apparently demanded the redevelopment plan and its associated takings as a quid pro quo for its agreement to build a new headquarters in New London." (citing Ted Mann, Pfizer's Fingerprints on Fort Trumbull Plan, The Day (Oct. 16, 2005)I).

${ }^{245}$ See Lefcoe, 17 S Cal Rev L \& Soc Just at 814 (cited in note 71) ("Suppose a redevelopment agency disregards its plan entirely, claims it is taking the property for one purpose or owner, and conveys it to another for an entirely different use?").
} 
these cases, officials are likely to claim that the transfer to a private party is justified because of a change in circumstances. A number of courts have permitted such takings even though the condemnor knew beforehand that the ultimate use would differ from the original public purpose. ${ }^{246}$

Conversely, local officials may attempt to rely on a past factual finding or previous blight determination to justify a project even though circumstances actually have changed. For example, in Aposporos v. Urban Redevelopment Commission, ${ }^{247}$ the redevelopment commission attempted to sell land to two developers in 1997 based on an urban renewal plan from 1988. ${ }^{248}$ Similarly, in Arvada Urban Renewal Authority v. Columbine Professional Plaza Association $(A U R A),{ }^{249}$ the urban renewal authority asserted that it retained the power to condemn land within an area previously designated as blighted "even though the entire parcel ha[d] been sold by the authority, developed in accordance with its urban renewal plan, and formally released by the authority." 250

Allowing a local government to exercise unfettered discretion in altering its previous plans or to rely on archaic factual findings in justifying its current plans would increase the likelihood of a pretextual taking. Fortunately, the possibility of pretext in these types of condemnations is typically easier to detect than other types of pretext. Although officials initially may claim that a taking is for one purpose, the subsequent transfer of the parcel to a private developer for a different purpose provides an objective, and easily observable, indication of impermissible favoritism.

Moreover, in response to these attempts to circumvent the condemnation process, some states have enacted constitutional amendments or statutory provisions that seek to prevent transfers to private parties based on changed circumstances. These restrictions give prior owners an option to repurchase their condemned land if the government is no longer using the land for its original public purpose. ${ }^{251}$ State courts, including the Connecticut Supreme Court in

${ }^{246}$ See id ("Professor Kanner recounts numerous cases where this happened, and courts refused to grant relief to the deceived owners-even when the agency knew at the time it was promulgating a plan that it would soon disregard." (citing Kanner, 39 Urb Law at 545-46 (cited in note 24)川).

247790 A2d 1167 (Conn 2002).

${ }^{248} \mathrm{Id}$ at $1170-72$.

24985 P3d 1066 (Colo 2004) (en banc).

${ }^{250}$ Id at 1067.

${ }^{251}$ See Lefcoe, 17 S Cal Rev L \& Soc Just 815 (cited in note 71) ("[M]any states even before Kelo had enacted statutes and constitutional amendments granting owners of property previously taken an option to repurchase once the acquiring agency declares the land to be surplus, no longer needed by the government and potentially available 
Aposporos and the Colorado Supreme Court in AURA, also have been active in prohibiting transfers that are based on archaic factual findings. ${ }^{252}$ Indeed, the holdings in Aposporos and AURA provide further evidence that state courts are becoming increasingly aware that private involvement is sometimes pretextual. ${ }^{253}$

\section{One-to-One Transfers}

While concerns regarding pretext arise most frequently in assembly projects, there is also a potential for pretext in situations involving one-to-one transfers. ${ }^{254}$ Many of the pre-Kelo cases in which courts held that a taking is pretextual involved such transfers. ${ }^{255}$ In Kelo itself, the Court warned that "a one-to-one transfer of property, executed outside the confines of an integrated development plan,... would certainly raise a suspicion that a private purpose was afoot ...."256 In a one-to-one transfer, the condemnor attempts to take property from private party $A$ and transfer it to private party $B$. Favoritism is possible because $B$ has an incentive to convince the government to invoke eminent domain on its behalf if $B$ 's acquisition costs would be lower through eminent domain than voluntary exchange. This type

for sale to the bidding public. Post-Kelo, other states are enacting such laws." (citing Lynda J. Oswald, Can the Condemnee Regain Its Property if the Condemnor Abandons the Public Use? 39 Urb Law 671, 680 (2007)I).

${ }^{252}$ See Aposporos, $790 \mathrm{~A} 2 \mathrm{~d}$ at 1175 ("We cannot conclude . . . that a redevelopment agency may make an initial finding of blight and rely on that finding indefinitely to amend and extend a redevelopment plan to respond to conditions that did not exist, or to accomplish objectives that were not contemplated, at the time that the original plan was adopted."); AURA, 85 P3d at 1067 ("[O]nce a parcel within a redevelopment area has been sold, developed, and released in this manner, an urban renewal authority may not exercise its condemnation power over any part of that parcel absent renewed findings of blight by the appropriate authority.").

${ }^{253}$ Cf. Merrill, 72 Cornell L Rev at 95-96 (cited in note 12) (surveying "all reported appellate cases decided between Berman $v$ Parker and January 1, 1986, that involved a contested public use question" and finding that "[s]tate courts ... seem more willing to depart from Berman's virtual abandonment of judicial review" I; Corey J. Wilk, The Struggle over the Public Use Clause: Survey of Holdings and Trends, 1986-2003, 39 Real Prop Prob \& Tr J 251, 258 (2004) (updating Merrill's survey and finding a similar percentage of state court decisions that held that a condemnation violated the public use requirement).

${ }^{254}$ See Kelly, 92 Cornell L Rev at 54 n 253 (cited in note 23) (noting that "municipalities and private developers also use eminent domain for the purpose of redeveloping single parcels of land").

${ }^{255}$ See Aaron v Target Corp., 269 F Supp 2d 1162 (ED Mo 2003), rev'd on other grounds, 356 F3d 768 (8th Cir 2003); 99 Cents Only Stores v Lancaster Redev Agency, 237 F Supp 2d 1123 (CD Cal 2001); Sw Ill Dev Auth v Nat'l City Envtl, LLC, 768 NE2d 1,10 (Ill 2002).

${ }^{256} \mathrm{Kelo}, 545$ US at 487 (emphasis added). 
of private involvement may lead to the same problems of corruption, secondary rent seeking, and threats to relocate as in assembly situations. ${ }^{257}$

Yet, one-to-one transfers differ from assembly projects in a fundamental respect: unlike assembly projects, one-to-one transfers do not involve the holdout problem. ${ }^{258}$ For this reason, such transfers usually can be accomplished through consensual, rather than forced, exchange. Consensual exchange is beneficial here not only because it ensures that transfers are welfare-enhancing but also because it eliminates the possibility of pretext. Thus, private involvement in the takings process should be reserved only for certain types of assembly projects.

One-to-one transfers could involve the problem of bilateral monopoly. In a bilateral monopoly, a situation involving a single buyer and a single seller, the buyer and seller both have an incentive to obtain as much of the surplus as possible. Strategic bargaining may increase transaction costs and, in some instances, such costs may surpass the benefits of the transaction. ${ }^{259}$ Consequently, a limited number of situations may exist in which eminent domain is necessary for a one-to-one transfer. For instance, when an individual owns a landlocked parcel, courts will sometimes grant an easement by necessity. ${ }^{260}$ The justification for such an easement is the potential bilateral monopoly problem that might exist between the landlocked owner and her neighbor. ${ }^{261}$

In most circumstances, however, the bilateral monopoly problem does not justify one-to-one takings on behalf of private parties.

${ }^{257}$ See Part II(A); see also Gillette, 34 Hofstra L Rev at 20 (cited in note 24) ("Just as spot zoning raises concerns that the person who got the exception had the fix in, ... so too are the conditions for deference relaxed where the takings decision implicates so few parcels that one reasonably fears a heightened risk of abuse.").

${ }^{258}$ See Kelly, 92 Cornell L Rev at $54 \mathrm{n} 253$ (cited in note 23) (pointing out that "private parties actually confront fewer bargaining problems for acquiring single properties than assembling multiple properties because the holdout problem disappears"); see also Law Professors Amicus Brief at * 19 (cited in note 83) (arguing that "no holdout problem can arise in one-to-one takings").

${ }^{259}$ See Merrill, 72 Cornell L Rev at 75 (cited in note 12) ("Such strategic bargaining in a bilateral monopoly situation increases the project's transaction costs, and if the transaction costs approach or exceed the project's gains, the [project] may never be built.").

${ }^{260}$ See Saul Levmore, Takings, Torts, and Special Interests, 77 Va L Rev 1333, 1339 n 8 (1991) (noting that the "doctrine of easement by necessity . . permits one property owner to use another's land when this use is found 'necessary' to the enjoyment of the first owner's land, as it might when a landlocked owner has no other means of access to his property").

${ }^{261}$ See Stewart E. Sterk, Neighbors in American Land Law, 87 Colum L Rev 55, 85 (1987) (discussing "the bilateral-monopoly justification for easements by necessity"). 
Often, a property owner will have other alternatives that prevent the owner's neighbor from attempting to extract the entire surplus. For example, in 99 Cents Only, Costco could have expanded its store in a different direction without demanding that the redevelopment agency condemn 99 Cents Only's leasehold interest. ${ }^{262}$ Therefore, there was no bilateral monopoly problem and no need for a private taking. Similarly, in Southwest Illinois Development Authority v. National City Environmental (SWIDA), ${ }^{263}$ the race track could have built a parking garage instead of requesting that the development authority take the land of its neighbor, a recycling facility, for a new parking lot. ${ }^{264}$ Once again, there was no bilateral monopoly problem and no need for a private taking. In highlighting these alternatives, the courts in both 99 Cents Only and SWIDA seemed to be relying implicitly on a type of least-restrictive-alternative requirement: if a private party attempts to utilize eminent domain to achieve a private objective, but the objective could be achieved in an alternative way, the taking is presumed to be pretextual.

\section{7. "Same-Use" Takings}

One-to-one transfers raise another possibility: namely, a condemnation may be pretextual not only because a private party is particularly favored but also because a party is particularly disfavored. ${ }^{265} \mathrm{~A}$ local government might decide to exercise eminent domain because it dislikes an owner or disapproves of the way in which the owner is utilizing her land. ${ }^{266}$ While discerning whether a particular party is disfavored may be even more difficult than determining whether a particular party is favored, ${ }^{267}$ one indication that a taking involves a

${ }^{262}$ See 99 Cents Only Stores, 237 F Supp 2d at 1129 ("It is . . undisputed that Costco could have easily expanded within the Power Center onto adjacent property without displacing 99 Cents at all but refused to do so.").

263768 NE2d 1 (Ill 2002).

${ }^{264} \mathrm{Id}$ at 10 (pointing out that "other options were available to Gateway that could have addressed many of the problems" and that "Gateway could have built a parking garage structure on its existing property rather than develop the land owned by NCE").

${ }^{265} \mathrm{Cf}$. Daniel A. Farber, Economic Analysis and Just Compensation, 12 Int'1 Rev L \& Econ 125, 137 (1992) (concluding that "the takings clause can be defended as a barrier against a serious form of discrimination against politically disfavored groups").

${ }^{266}$ See Oswald, 35 BC Envtl Aff L Rev at 47 (cited in note 44) (discussing situations in which "the condemning authority condemns to prevent an undesirable use—or, at least, one undesired by the condemnor or its most vocal constituents-be it a landfill, low-income housing, a rehabilitation facility, or any other NIMBY-triggering use").

${ }^{267} \mathrm{Cf}$. id ("Although public use itself is a difficult concept for courts to wrest with, the non-use cases seem to pose even tougher analytical hurdles for the courts."). 
disfavored party is if the land's post-condemnation use is equivalent to the land's pre-condemnation use.

For example, shortly after Kelo, local officials in North Hills, New York attempted to condemn Deepdale Golf Club, a private golf course, and convert it into a public golf course. ${ }^{268}$ One Deepdale member asked: "Someone can take your golf course, and give it to someone else as a golf course?"269 The threatened condemnation of Deepdale sparked widespread opposition, with critics pointing out that the condemnation makes "no economic sense." ${ }^{270}$ Eventually, the New York State Assembly enacted legislation that prohibits officials from condemning recreational facilities such as Deepdale. ${ }^{271}$

Similarly, the Rhode Island Development Corporation recently attempted to use its "quick take" authority to condemn a temporary easement in a multi-million dollar airport parking facility. ${ }^{272}$ The development corporation argued that the condemnation's primary purpose was to increase the number of available parking spots. ${ }^{273} \mathrm{But}$, on appeal, the Rhode Island Supreme Court pointed out that "no additional parking spaces were created" and that the only change in use appeared to be that "those parking spaces previously dedicated to valet parking simply were reallocated for daily parking. ${ }^{\prime 274}$ Ultimately, the Court invalidated the condemnation. ${ }^{275}$

The use of eminent domain normally requires a post-condemnation use that is at least ostensibly of greater value than the pre-condemnation use. The problem with "same-use" takings, like the threatened condemnation of Deepdale Golf Club or the attempted condemnation of the airport parking easement, is that these takings not only entail a risk of disfavoritism but also have no ostensible economic benefit. ${ }^{276}$

${ }^{268}$ See Peter Applebome, Of the Rich, Eminent Domain ... and Golf, NY Times, 29 (Mar 26, 2006).

${ }^{269} \mathrm{Id}$ (quoting John Wilson).

${ }^{270}$ Joseph A. Grundfest, Out of Bounds, NY Times 9 (Apr 16, 2006) (opining that "the Deepdale land grab makes sense only if ... North Hills can take the golf course for less than 100 cents on the dollar").

${ }^{271}$ See Julia C. Mead, Law Shuts Door on an Open-Space Gambit, NY Times, 2 (Aug 27, 2006).

${ }_{272}^{27}$ I Econ Dev Corp v The Parking Co, 892 A2d 87, 91 (RI 2006).

${ }^{273}$ Id at 105.

${ }^{274} \mathrm{Id}$.

${ }^{275}$ Id at $107-08$.

${ }^{276}$ It is doubtful whether local officials in New York would have been in the best position to determine whether Deepdale would have a higher value as a public, rather than private, golf course. Even if a different fee or membership plan might enhance the parcel's value, the course's existing owners seemingly would have an incentive to implement such a plan. Likewise, it is doubtful whether the redevelopment corporation in Rhode Island would be in a better position than the parking garage's current 
Because of the possibility that the condemnor's actual motive may be to disfavor a particular private party, such takings also should be considered pretextual. ${ }^{277}$

\section{CON CLUSION}

In this Article, I have proposed a framework for identifying pretextual takings based on the comparative competencies of local governments and private developers. When the government lacks information regarding the optimal site for an assembly, the government may need to rely on a private developer to identify, as well as execute, an assembly project. However, when the government itself possesses information regarding the appropriate site, pre-condemnation private involvement, as well as post-condemnation involvement by a preferred private developer, is generally unnecessary.

Consequently, if a private developer is expected to obtain a distinct benefit from a condemnation, the government should be required to

operators to determine whether valet parking spaces should be reallocated for daily parking. Presumably, if a different allocation was more desirable, the current operators could reconfigure the spaces accordingly.

${ }^{277}$ There are several other types of takings in which pretext is an issue because the condemnee is a disfavored party. In these cases, like the "same use" takings, the government, not a private party, is often the ultimate owner of the land. However, unlike "same use" takings, the government might attempt to alter the land use to a different use that is a traditional public use. See, for example, Oswald, 35 BC Envtl Aff L Rev at 65-68 (cited in note 44) (discussing two cases in which the Georgia Supreme Court invalidated condemnations even though the asserted public purposes were traditional public uses (in one case, a public park; in the other, a training area for police and fire officials)|. The takings in these types of cases, however, often entail direct evidence of a discriminatory purpose either because the condemnor is targeting individuals on the basis of a suspect classification such as race, see, for example, Deerfield Park Dist. v Progress Dev Corp, 174 NE2d 850 (Ill 1961) (reversing judgment of trial court in favor of condemnor park district where condemnee had alleged in complaint that park district had used power of eminent domain to prevent development of integrated neighborhood in violation of the Equal Protection Clause), or religion, see, for example, Albanian Associated Fund v Twp of Wayne, 2007 U.S. Dist. LEXIS 73176, 2007 WL 2904194 (DNJ 2007) (denying town's motion for summary judgment because plaintiff alleged that attempted condemnation of mosque for purpose of establishing "open space" was pretextual and violated the Free Exercise Clause and the Religious Land Use and Institutionalized Persons Act of 2000), or because the condemnor is clearly acting in bad faith, see, for example, Borough of Essex Falls v Kessler Institute for Rehabilitation, Inc, 673 A2d 856, 860-62 (NJ Super Ct Law Div 1995) (concluding that borough's asserted purpose for condemning a parcel, to create additional park land, was a mere pretext for preventing the establishment of rehabilitation facility). Cf. Vill of Arlington Heights v Metro Hous Dev Corp, 429 US 252, 265-66 (1977) (pointing out that "judicial deference is no longer justified" when there is "proof that a discriminatory purpose has been a motivating factor in the decision"). 
provide a legitimate justification for the particular type of private involvement at issue. Ultimately, such an approach could be implemented using a burden-shifting framework similar to the test for identifying pretext in Title VII cases.

Without a coherent doctrinal framework, courts may still identify certain takings as pretextual. For example, courts may view oneto-one takings or condemnations in which the post-condemnation use is the same as the pre-condemnation use with suspicion. But most other condemnations, including almost all assembly projects of any considerable size, would likely invoke only minimal judicial scrutiny. Because the projected public benefits of these condemnations are typically significant, courts would continue to defer to legislative determinations regarding the necessity of private involvement, even if the reasons for such private involvement are unclear.

Yet the problem with the lack of a coherent framework is not only excessive judicial deference but also excessive judicial discretion. Unlimited discretion would permit a court to invoke the pretextual takings doctrine selectively. A court might allow a particular assembly of which it approves even though there is a substantial risk of favoritism and disallow another assembly of which it disapproves even though there is little or no risk of favoritism. Developing a jurisprudence of pretext may be necessary, therefore, to prevent the emergence of a jurisprudence that is itself pretextual. 